\title{
Immunocompetent Mouse Models in the Search for Effective Immunotherapy in Glioblastoma
}

\author{
Roxanne Wouters ${ }^{1,2,+}$, Sien Bevers ${ }^{1,3,+}+$, , Matteo Riva ${ }^{1,4}$, Frederik De Smet ${ }^{3}\left(\mathbb{D}\right.$ and An Coosemans ${ }^{1, *}(\mathbb{C}$ \\ 1 Laboratory of Tumor Immunology and Immunotherapy, Department of Oncology, Leuven Cancer Institute, \\ KU Leuven, 3000 Leuven, Belgium; roxanne.wouters@kuleuven.be (R.W.); sien.bevers@kuleuven.be (S.B.); \\ matteo.riva@kuleuven.be (M.R.) \\ 2 Oncoinvent, A.S., 0484 Oslo, Norway \\ 3 The Laboratory for Precision Cancer Medicine, Translational Cell and Tissue Research Unit, Department of \\ Imaging and Pathology, KU Leuven, 3000 Leuven, Belgium; frederik.desmet@kuleuven.be \\ 4 Department of Neurosurgery, Mont-Godinne Hospital, UCL Namur, 5530 Yvoir, Belgium \\ * Correspondence: an.coosemans@kuleuven.be \\ + These authors contributed equally to this paper.
}

Citation: Wouters, R.; Bevers, S.; Riva, M.; De Smet, F.; Coosemans, A. Immunocompetent Mouse Models in the Search for Effective Immunotherapy in Glioblastoma. Cancers 2021, 13, 19. https:/ / dx.doi.org/10.3390/cancers 13010019

Received: 30 November 2020 Accepted: 20 December 2020 Published: 23 December 2020

Publisher's Note: MDPI stays neutral with regard to jurisdictional claims in published maps and institutional affiliations.

Copyright: () 2020 by the authors. Licensee MDPI, Basel, Switzerland. This article is an open access article distributed under the terms and conditions of the Creative Commons Attribution (CC BY) license (https: / / creativecommons.org/ licenses/by/4.0/).
Simple Summary: Glioblastoma (GBM) remains the most aggressive brain tumor. Treatment typically includes surgery and radio/chemotherapy, but in spite of intensive treatment, virtually all tumors recur within the time-frame of months with insufficient and unsuccessful second line options. This clinical reality is in contrast to preclinical animal experiments, which often show successful outcomes of novel immunotherapeutic approaches. This discrepancy is largely explained by the small number of animal models and their limited capacity to mimic the complexity of the human disease. Moreover, new treatment options are typically administered as single treatments in animal models, whereas patients receive them in combination with standard-of-care. In this review, we provide an overview of the existing mouse models for GBM research and how each of them mimic (parts of) the human disease spectrum. As such we provide an overview of the advantages and limitations of the currently available options for in vivo drug testing for GBM.

Abstract: Glioblastoma (GBM) is the most aggressive intrinsic brain tumor in adults. Despite maximal therapy consisting of surgery and radio/chemotherapy, GBM remains largely incurable with a median survival of less than 15 months. GBM has a strong immunosuppressive nature with a multitude of tumor and microenvironment (TME) derived factors that prohibit an effective immune response. To date, all clinical trials failed to provide lasting clinical efficacy, despite the relatively high success rates of preclinical studies to show effectivity of immunotherapy. Various factors may explain this discrepancy, including the inability of a single mouse model to fully recapitulate the complexity and heterogeneity of GBM. It is therefore critical to understand the features and limitations of each model, which should probably be combined to grab the full spectrum of the disease. In this review, we summarize the available knowledge concerning immune composition, stem cell characteristics and response to standard-of-care and immunotherapeutics for the most commonly available immunocompetent mouse models of GBM.

Keywords: glioblastoma; immunotherapy; model; animal model; preclinical; murine; immune response

\section{Introduction}

Glioblastoma (GBM), is the most lethal brain tumor in adults, despite all therapeutic efforts [1,2]. After standard-of-care treatment, consisting of maximal surgical resection followed by radiotherapy (RT) and adjuvant temozolomide (TMZ), the median overall survival generally does not exceed 15 months [3-5]. This underscores the unmet medical need for the development of more efficient treatments. Several immunotherapeutic 
strategies, such as immune checkpoint inhibitors, cellular therapies and oncolytic viral therapies, have been explored in GBM [6,7]. However, to date all randomized clinical trials failed to provide lasting clinical efficacy [8-12], despite the many successes of pre-clinical studies [13-15]. We are therefore facing an important translational gap.

We believe that the discrepancy between preclinical and clinical results for immunotherapy in GBM can be explained by several factors, two of which play a pivotal role. First, current experimental models probably insufficiently mimic the complex situation in the human brain and are therefore unable to adequately predict the clinical scenario. In particular, the immune suppressive tumor microenvironment and its impact on immunotherapy has been mostly ignored or insufficiently characterized in previous preclinical studies [16,17]. Second, preclinical studies have rarely implemented the standard-of-care treatment (surgery, RT and TMZ) when testing the effect of immune modulators. This issue is particularly relevant for immunotherapy, since conventional treatments can modify the immune biology of GBM thereby altering the response to additional immunotherapy [8,18-21].

We believe that addressing these two problems would strongly boost the translational impact of GBM preclinical studies. However, integrating the full standard-of-care in preclinical research is challenging and require specific neurosurgical skills and equipment, which are not always available. Conversely, preclinical testing with multiple immunocompetent mouse models in order to better recapitulate multiple aspects of GBM biology and inter-patient heterogeneity is relatively straightforward. Nevertheless, to this end it is essential to know all relevant features of the available tumor models [22-29], in order to make an appropriate evaluation of which are the most adequate for each specific research question.

In this review, we will summarize the main features of the most relevant immunocompetent GBM mouse models (Tables 1 and 2). For each model, we collected the available information on tumor immunity, cancer stemness, response to standard-of-care treatment and the effect of immunotherapeutics. The final goal will be to provide a useful tool for model selection and combination for the preclinical testing of new immunotherapeutic approaches against GBM.

\section{Oldest Available Immunocompetent Mouse Models for GBM}

The development and characterization of these oldest models has already been reviewed in detail in a previous publication by Oh et al. in 2014 [30]. Therefore, for these older models we will mainly focus on their most recent developments. An overview of these mouse models and relevant information can be found in Figure 1 and Table 1. 
Table 1. Overview of the different characteristics of the GL26, GL261, ML/CT-2A, SMA-560 and 4C8 mouse models.

\begin{tabular}{|c|c|c|c|c|c|c|c|c|}
\hline Model & Host & Induction & Histology & Immune Composition & Stem Cells & $\begin{array}{c}\text { Effect of } \\
\text { Standard-of-Care } \\
\text { Therapy }\end{array}$ & $\begin{array}{c}\text { Response to } \\
\text { Immunotherapy }\end{array}$ & Reference \\
\hline GL261 & C57BL/ 6 & $\begin{array}{l}\text { Chemical } \\
\text { induction with } \\
\text { methylcholan- } \\
\text { threne }\end{array}$ & $\begin{array}{l}\text { GBM, ependy- } \\
\text { moblastoma }\end{array}$ & $\begin{array}{l}\text { Immunogenic profile with high } \\
\text { of frequency activated } \\
\text { microglia and } \mathrm{CD}^{+} \mathrm{T} \text { cells, low } \\
\text { frequency of Tregs, presence of } \\
\text { TAMs, low frequency of APCs }\end{array}$ & $\begin{array}{l}\text { Stem cell like } \\
\text { phenotype with } \\
\text { Nestin and CD133 } \\
\text { expression }\end{array}$ & $\begin{array}{l}\text { RT: +/- } \\
\text { TMZ: + }\end{array}$ & $\begin{array}{l}\text { Survival benefit with } \\
\text { several } \\
\text { immunotherapeutic } \\
\text { strategies in single and } \\
\text { combination treatment } \\
\text { (ICB, vaccination, } \\
\text { virotherapy,... ) }\end{array}$ & $\begin{array}{l}\text { Ausman } 1970 \\
{[15,21,31-115]}\end{array}$ \\
\hline GL26 & C57BL/ 6 & $\begin{array}{l}\text { Chemical } \\
\text { induction with } \\
\text { carcinogen } \\
\text { implantation }\end{array}$ & $\begin{array}{l}\text { GBM, ependy- } \\
\text { moblastoma }\end{array}$ & $\begin{array}{l}\mathrm{CD}^{+} \mathrm{T} \text { cell and myeloid cell } \\
\text { infiltration with high } \\
\text { expression of PD-1 and TIGIT } \\
\text { immune checkpoints }\end{array}$ & $\begin{array}{l}\text { Gene expression } \\
\text { profile of glioma } \\
\text { stem cells }\end{array}$ & TMZ: + & Generally positive & $\begin{array}{c}\text { Sugiura } 1969 \\
\text { [116-130] }\end{array}$ \\
\hline ML/CT-2A & C57BL/ 6 & $\begin{array}{l}\text { Chemical } \\
\text { induction with } \\
\text { methylcholan- } \\
\text { threne }\end{array}$ & $\begin{array}{l}\text { Anaplastic } \\
\text { astrocytoma }\end{array}$ & $\begin{array}{l}\text { Overall immune suppressive } \\
\text { microenvironment with low } \\
\text { numbers of microglia, high } \\
\text { numbers of resident } \\
\text { macrophages and exhausted } \\
\text { CD8 }{ }^{+} \text {T cells with TIM- } 3 \text { and } \\
\text { LAG-3 expression }\end{array}$ & $\begin{array}{l}\text { Positive for CD133, } \\
\text { Nestin and Oct } 4 \\
\text { stem cell markers }\end{array}$ & RT: - & Generally positive & $\begin{array}{c}\text { Seyfried } 1992 \\
{[26,33,77,131-147]}\end{array}$ \\
\hline SMA-560 & $\mathrm{VM} / \mathrm{Dk}$ & Spontaneous & $\begin{array}{l}\text { Anaplastic } \\
\text { astrocytoma }\end{array}$ & $\begin{array}{l}\text { Upregulation } \\
\text { immunoregulatory pathways, } \\
\text { TGF- } \beta \text { signaling }\end{array}$ & $\begin{array}{l}\text { CD44 and Nestin } \\
\text { expression when } \\
\text { cultured in } \\
\text { spheres }\end{array}$ & $\begin{array}{l}\text { RT: - } \\
\text { TMZ: - }\end{array}$ & Generally positive & $\begin{array}{c}\text { Fraser } 1971 \\
{[134,148-160]}\end{array}$ \\
\hline $4 \mathrm{C} 8$ & B6D2F1 & $\begin{array}{l}\text { Clonal cell lines of } \\
\text { a glial tumor from } \\
\text { a transgenic } \\
\text { mouse }\end{array}$ & $\begin{array}{l}\text { Oligodendroglioma, } \\
\text { astrocytoma }\end{array}$ & $\begin{array}{l}\text { Large number of macrophages } \\
\text { at the tumor periphery instead } \\
\text { of in the tumor core }\end{array}$ & Not assessed & Not assessed & $\begin{array}{c}\text { Generally positive } \\
\text { (limited amount of data } \\
\text { available) }\end{array}$ & $\begin{array}{l}\text { Weiner } 1999 \\
\text { [161-165] }\end{array}$ \\
\hline
\end{tabular}

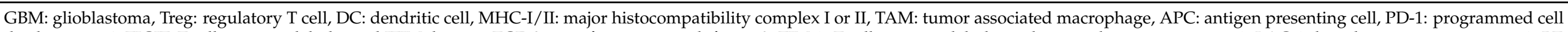

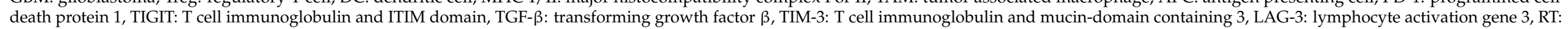
radiotherapy, TMZ: Temozolomide, ICB: immune checkpoint blockade. Bold: highlight. 


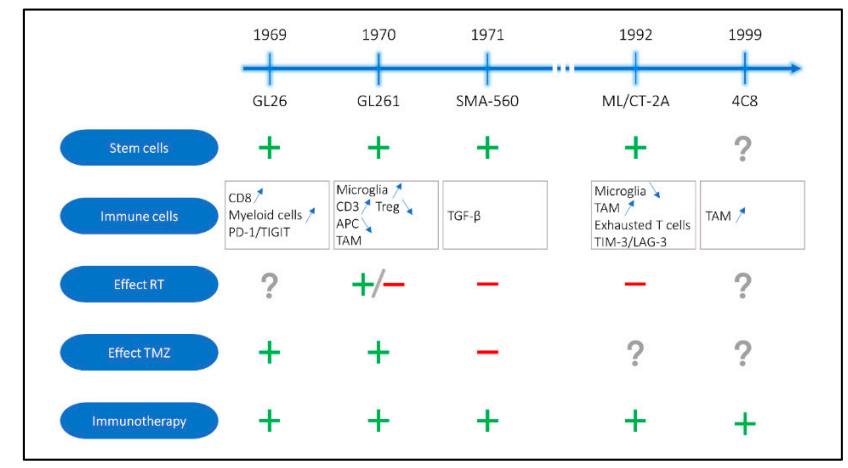

Figure 1. Schematic and chronological presentation of the old preclinical immunocompetent mouse models for glioblastoma with information about stemness, immune cell composition, the effects of standard of care and the efficiency of immunotherapy. RT: radiotherapy, TMZ: Temozolomide, PD-1: programmed cell death protein 1, TIGIT: T cell immunoglobulin and ITIM domain, Treg: regulatory T cell, TAM: tumor associated macrophage, TGF- $\beta$ : transforming growth factor $\beta$, TIM- 3 : T cell immunoglobulin and mucin-domain containing 3, LAG-3: lymphocyte activation gene $3,(+)$ presence of stem cell populations and/or positive effect of treatment administration, (-) no effect of treatment administration and (?) data not available in literature.

\subsection{GL261}

\subsubsection{Origins and Tumor Characteristics}

This chemically induced model was first developed in 1970 by Ausman et al. [116]. and has by far been the most widely used in glioblastoma research. In vivo, GL261 cells have been shown to express different general stem cell markers such as CD133 and nestin [31] while exhibiting infiltrative capacity of brain-tumor derived mesenchymal stem cells positive for Sox2, nestin, Sca-1, CD9, CD44 and CD166 [32]. Khalsa et al. performed a bulk RNA sequencing analysis on GL261 tumors which showed a strong enrichment of differentially expressed genes related to several immune pathways compared to naïve control mice, especially related to genes relevant for $\mathrm{T}$ cells, macrophages and eosinophils [33]. The same study also indicated a higher frequency of activated microglia, more total $\mathrm{T}$ cells, a lower frequency of regulatory T cells and antigen presenting cells compared to the ML/CT-2A tumor model [33]. All findings point towards the fact that the GL261 tumor model is more immunogenic than other models, such as the ML/CT-2A tumor model.

\subsubsection{Effect of Standard-of-Care}

Both whole brain and focal beam irradiation strategies have been evaluated in the GL261 model. While whole brian irradiation was able to prolong survival and deliver long-term surviving mice, focal beam irradiation didn't show the same potential [34-37]. Administration of TMZ was able to provide similar survival benefits in the GL261 model as is seen in GBM patients [38-40].

\subsubsection{Immunotherapeutic Approaches}

Many different immunotherapies have been tested in the GL261 model. These include studies investigating programmed cell death protein 1 (PD-1) checkpoint blockade or other immune checkpoint inhibitors, oncolytic virotherapy, chimeric antigen receptor (CAR) T cell therapy, dendritic cell vaccination and many others [15,35,41-84]. In addition, the efficacy of many other less common immunotherapeutic approaches have been investigated in the GL261 models [85-109]. The vast majority of these therapies showed promising results, with a stronger anti-tumor response and improved survival rates. These immunotherapeutic strategies have been investigated as single treatments, in combination with other types of immunotherapies or in combination with the standard-of-care treatment. However, only part of the standard-of-care (usually TMZ, less commonly RT or RT-TMZ) was taken into consideration $[39,40,78,79,110-114]$. Interestingly, the efficacy of checkpoint inhibition 
directed against PD-1 or its ligand (PD-L1) in combination with TMZ, RT, or both was tested in six, two or one preclinical studies, respectively. Out of these eight combinatorial studies, seven were conducted with the GL261 tumor model [21].

The effects of steroids, largely used in the clinic to reduce brain oedema in GBM patients, were analyzed in one study using the GL261 tumor model. This study demonstrates that steroids have an inhibitory effect on anti-tumor immunity and that blocking cytotoxic T-lymphocyte-associated protein 4 (CTLA-4), but not PD-1, could partially prevent such negative modulation [115].

\subsection{GL26}

\subsubsection{Origins and Tumor Characteristics}

The GL26 model is the oldest immunocompetent preclinical model for GBM and has been developed in 1969 by chemical induction [116]. It has been less extensively used than the (similar) GL261 model. Although both models show a great histological resemblance, the main difference is that GL26 tumors show a large extent of necrosis and vascularity and therefore tend to be more hemorrhagic [116]. Crommentuijn et al. [117] described the presence of a tumor antigen-specific $\mathrm{CD} 8^{+} \mathrm{T}$ cell population which displays a tolerogenic phenotype with a high expression of several immune checkpoints such as PD-1 and T cell immunoglobulin and ITIM domain (TIGIT). The infiltration of myeloid cells expressing these immune checkpoint ligands was also observed [117]. Furthermore, the importance of galactokinase (Gal1) in the immune suppression of the GL26 model was described, since it masks tumor cells from immune recognition $[118,119]$. The importance of glial toll-like receptor 2 (TLR2) as a bridge between the innate and the adaptive immune response was also reported, which is crucial in providing an effective immune response against the tumor [120]. Genetic analysis of GL26 tumors also revealed a specific acquisition of several stem cell markers that were correlated to anti-tumor T cell activity [121].

\subsubsection{Effect of Standard-of-Care}

Radiotherapy (also if as whole body irradiation) and TMZ as a monotherapies have both been proven to be effective in prolonging survival in the GL26 mouse model [122-126]. Furthermore, TMZ treatment was able to increase cross-priming of tumor antigen-specific $\mathrm{CD}^{+} \mathrm{T}$ cells and $\mathrm{CD} 8^{+} \mathrm{T}$ cells and suppressed the frequency of regulatory $\mathrm{T}$ cells (Tregs) [125].

\subsubsection{Immunotherapeutic Approaches}

GBM is strongly invasive and tumor cells can be found embedded in the normal parenchyma at great distance from the main tumor. This makes a complete resection not feasible [117]. Yadav et al. analyzed this problem with the GL26 model, and they found that down regulation of C-X-C chemokine receptor type 4 (CXCR4) led to less perivascular invasion and increased survival. Furthermore, CXCR4 knockdown sensitizes the tumors to irradiation, making this molecule an interesting therapeutic target [127]. Another novel therapeutic strategy targets the proton $/ \mathrm{H}^{+}$eflux mechanism important for the maintance of the intracellular $\mathrm{pH}$. The inhibition of the $\mathrm{H}+$ eflux mechanism (NHE1) reduced tumor volume, invasion and prolonged overall survival in GL26 (and SB28) glioma models. This type of treatment resulted in an accumulation of $\mathrm{CD}^{+} \mathrm{T}$ cells and sensitized animals to anti-PD-1 therapy [128]. Also the mTOR pathway is a frequent target of anti-glioma therapy. Targeting this pathway with rapamycin in combination with immunotherapy had a synergistic effect and a long term survival advantage. Rapamycin administration also resulted in a long lasting central memory $\mathrm{CD} 8^{+} \mathrm{T}$ cell response and a stronger antitumor response after a second tumor challenge [129]. The combination of TMZ with interferon (IFN)- $\beta$ was also tested in the GL26 model and showed enhanced anti-tumor effects compared to TMZ alone [130]. 


\section{3. $M L / C T-2 A$}

\subsubsection{Origins and Tumor Characteristics}

The CT-2A model was first described by Seyfried et al. in 1992 [131] and accurately represents numerous GBM characteristics, including the intra-tumoral cellular heterogeneity and the proliferative and metabolic profiles [132]. CT-2A cells cultured as monolayer cells (ML/CT-2A) in vitro express different stem cell markers such as CD133, nestin and Oct4 [26]. Also in vivo the expression of CD133 and Nestin is observed in ML/CT-2A tumors [133], indicating that the cells keep their stemness during tumor growth in mice. Khalsa et al. performed RNA sequencing to identify the ML/CT-2A immune profile in vitro [33]. In contrast to the highly immunogenic GL261 model, ML/CT-2A cells showed no enrichment of any immune response-related pathway. In vivo, ML/CT-2A tumors had lower numbers of $\mathrm{CD} 45^{\text {low }} \mathrm{CD} 11 \mathrm{~b}^{\text {low }} \mathrm{CX} 3 \mathrm{CR} 1^{+}$microglial cells (considered activated or resting based on MHCII positive or negative staining, respectively), but higher numbers of $\mathrm{CD} 11 \mathrm{~b}^{+} \mathrm{F} 4 / 80^{+} \mathrm{CD} 64^{+} \mathrm{Ly} 6 \mathrm{C}^{-}$resident macrophages and $\mathrm{CD} 39^{+} \mathrm{Tim}^{+} \mathrm{Lag} 3^{+} \mathrm{CD} 8^{+}$exhausted cytotoxic $\mathrm{T}$ cells compared to other glioblastoma tumor models. Furthermore, $70-80 \%$ of T cells in the tumor microenvironment of ML/CT-2A tumors exhibit prolonged expression of $\mathrm{T}$ cell immunoglobulin and mucin domain-containing protein 3 (TIM-3) and lymphocyte-activation gene 3 (LAG-3), both markers for dysfunctional T cells [33]. Overall, the ML/CT-2A model is characterized by an immune suppressive tumor microenvironment and exhausted effector $\mathrm{T}$ cell function, making it a very suitable tumor model for GBM research in the field of immunotherapy since a similar immune phenotype is observed in GBM patients [134].

\subsubsection{Effect of Standard-of-Care}

The ML/CT-2A model has not been widely used in preclinical studies assessing the effects of the standard-of-care treatment. Only one study described the effects of RT in the model [135], where whole brain irradiation was ineffective in prolonging survival in mice. As already mentioned, the surgical removal has an influence on the immune composition of the remaining/recurrent tumor, with obvious implications for immunotherapies. Nevertheless, this treatment has only occasionally been assessed in preclinical studies. Khalsa et al. performed an immunophenotyping of the ML/CT-2A mouse model before and after surgical resection of the tumor [33]. After tumor resection, an increase of $\mathrm{CD} 4^{+}$and $\mathrm{CD} 8^{+} \mathrm{T}$ cells and activated microglia was observed with a decrease of resting macrophages and resident microglia. Furthermore, PD-1 expression decreased and CD25 expression increased on $\mathrm{CD}^{+} \mathrm{T}$ cells post-tumor resection [33]. These data suggest that tumor resection in the ML/CT-2A model partially removes the immune suppressive microenvironment and promotes immune activation, possibly creating a favorable momentum for administration of immunotherapies.

\subsubsection{Immunotherapeutic Approaches}

Given the disappointing results of checkpoint blockade in GBM patients, the current focus of preclinical research in this field is on combining checkpoint blockade with newly identified targets such as interleukin 6 (IL-6), IL-7, IL-12 or phagocytosis pathways, in order to overcome T cell exhaustion [136-138]. In the ML/CT-2A tumor model, the combination of PD-1 checkpoint inhibition with anti-CD137 decreased TIL exhaustion, improved TIL functionality and resulted in 50\% long term survivors [139]. Another novel combination treatment recently tested was the combination of anti-PD-L1 with gene-mediated cytotoxic immunotherapy which resulted in more long term survivors as compared to the monotherapies [140]. One last focus of interest has been to improve the delivery of checkpoint inhibitors via lipid nanoparticles. In combination with RT, this strategy led to a depletion of tumor-associated myeloid cells and a significantly improved survival in ML/CT-2A and GL261 models [135].

Oncolytic virus (OV) therapy has great potential for success, however the best balance between maximal anti-tumor activity and acceptable toxicity is difficult to find, especially 
following direct intracranial infusion. Certain OVs based on herpes simplex virus (HSV) are safe but have only little anti-tumor response. To overcome this limitation Passaro et al. engineered an HSV to express an antibody against PD-1 and injected it intratumorally. This resulted in an increased median survival and immune memory against the both ML/CT-2A and GL261 tumors [141]. The combination of OV therapy with PD-1/PD-L1 immunotherapy provided a synergistic effect leading to an improved overall survival and an activation of the immune response capable to reverse the tumor-induced immune suppression $[142,143]$. On the other hand, OVs based on vesicular stomatitis virus (VSV) have a very robust anti-tumor effect but are extremely neurotoxic when injected in the brain. Therefore, Balathasan et al. [144] used an intravenous pretreatment of VSV $\Delta 51$ as a way to induce peripheral immunization before intracranial injection of an otherwise lethal dose of VSV $\Delta 51$. This resulted in complete tumor regression in 20\% of ML/CT-2A tumor bearing mice. Also OVs based on Semliki Forest Virus (SFV) have been developed $[145,146]$. When injected intravenously, they resulted in a prolonged survival with $27 \%$ of the mice bearing ML/CT-2A tumors cured, whereas there was no significant effect in the GL261 model [146].

In an interesting study, Ladomersky et al. used the ML/CT-2A model to demonstrate increased immune suppression, decreased immunotherapeutic efficacy and decreased survival in old age animals (75 week old mice, corresponding to 58-59 year old humans) [77]. The impact of age on GBM development and treatment has been ignored most of times: in the majority of studies, animals of young age (6-12 weeks, corresponding to early adulthood in humans) are used for preclinical GBM research [147]. Given that the median age at diagnosis for GBM is 65 years, the age difference between tumor models and patients is extremely relevant.

\section{4. $S M A-560$}

\subsubsection{Origins and Tumor Characteristics}

The SMA-560 model is one of the few models that spontaneously arose in VM/Dk mice as initially described by Fraser et al. in 1971 [148]. It was established as a cell line in 1980 by Serano and colleagues [149]. The fact that the model developed spontaneously in immunocompetent mice, makes it a very interesting model to study. A genetic characterization of the model revealed an upregulation of genes involved in antigen presentation, interferon-related protein expression and a general increase in genes related to immunoregulatory pathways indicating the presence of an ineffective immune response in the tumor microenvironment of the SMA-560 model [150]. Furthermore, the immune suppressive protein transforming growth factor beta (TGF- $\beta$ ) has been shown to play an important role in SMA-560 tumor development [151]. The expression of PD-1, TIM-3 and LAG-3 on tumor infiltrating lymphocytes is also increased in SMA-560 tumors [134]. In terms of stemness characteristics, it has been described that in vitro SMA-560 cells express only a limited amount of CD44 and nestin stem cell markers. However, when cultured in sphere cultures the cells seem to increase their CD44 and Nestin expression, which was correlated with a more aggressive tumor behaviour in vivo [152]. Schneider and colleagues described the difference in tumorigeneic potential in young and old VM/Dk mice. Interestingly at baseline, older SMA-560 mice had a significantly worse survival as compared to younger mice, in contrast to the GL261 model where this difference was not observed [153].

\subsubsection{Effect of Standard-of-Care}

In vitro, SMA-560 cells were highly resistant to TMZ treatment and only responded to high doses of irradiation [152]. However, only a few studies assessed these effects in vivo [154]. Whole brain irradiation as a single treatment or combined with TMZ was either ineffective or provided only a limited and non-significant improvement in survival compared to control mice $[154,155]$. This indicates that the standard-of-care used in GBM patients is ineffective in prolonging survival of the SMA-560 mouse model. Therefore, the translational potential of the model should be considered carefully when translating results 
to the whole GBM patient population. However, a tumor model that does not respond to RT or TMZ can be relevant in studying treatment options for patients who respond poorly to this standard-of-care treatment regimen or for the recurrent situation where resistance appeared.

\subsubsection{Immunotherapeutic Approaches}

An important immunological therapeutic target studied in the SMA-560 model is excessive TGF- $\beta$ signaling $[156,157]$. As such, the administration of phosphorothioate-locked nucleic acid (LNA)-modified antisense oligonucleotide gapmers targetting TGF- $\beta$ resulted in prolonged survival and increased $\mathrm{CD}^{+}$and $\mathrm{CD} 8^{+}$cytotoxic $\mathrm{T}$ cell infiltration [158]. Another emerging treatment strategy that has been tested in this model is CAR T cell therapy, which was shown to generate a pro-inflammatory tumor microenvironment and to significantly extend survival in the SMA-560 model [159]. Furthermore, anti-angiogenic treatment has a positive effect on survival in the SMA-560 model [155]. One of the problems in GBM treatment is the delivery of the compound trough the blood brain barrier. In this regard, microbubbles have been tested to increase the local concentration of certain types of treatments. This strategy was succesfully tested for doxorubicin in the SMA-560 model [160].

\section{5. $\mathrm{C} 8$}

\subsubsection{Origins and Tumor Characteristics}

The 4C8 model was established in 1999 from clonal cell lines of a glial tumor $(\mathrm{MOCH}-$ 1) in B6D2F1 mice [161]. Gazdzinski et al. [162] compared the characteristics of this model with the GL261 model. The 4C8 model is less aggressive, the tumor has higher cell density, less necrosis and invasiveness with a more normal vasculature and less mitotic cells as compared to the GL261 model. Both models have a large number of infiltrating macrophages; however, these cells are located at the tumor periphery in the $4 \mathrm{C} 8$ model [162]. All these features, consistently pointing towards a lower aggressiveness in comparison to the GL261 model, have strongly limited the used of the 4C8 tumor model.

\subsubsection{Immunotherapeutic Approaches}

This model has been used very limitedly in immunotherapeutic or anti-angiogenic research $[163,164]$. The combination of an anti-angiogenic receptor tyrosine kinase inhibitor with a proteasome inhibitor resulted in a significantly improved survival and an induction of anti-angiogenic effects which leads to vascular normalization [164]. The effects of oncolytic virotherapy were assessed in the model as well. In vitro, 4C8 cells showed the same sensitivity as human glioma cells to a series of type HSV-1 [165]. In vivo studies showed a prolongation of survival with an intracranial injection of an IL-12-expressing HSV [165].

\section{Recently Developed Immunocompetent Mouse Models for GBM}

Various new GBM models have been developed in the last years. In most cases, this has been done by means of viral vectors which were either used to manipulate isolated mouse cells (mGB2, NSCL61 and bTiTs-G3) or injected directly into the animals' brain (SB28, 005 GSC and NFpp10 models). Additionally, tumor models have been generated from spontaneously developed tumors in genetically altered mice (KR158B and Mut3) or by culturing older cell lines in a different way (CT-2A). In all cases, stable cells lines amenable of standard intracranial injection have been obtained [22-25,27,28,166]. An overview of these mouse models and relevant information can be found in Figure 2 and Table 2. 
Table 2. Overview of the different characteristics of the KR158B, Mut3, 005 GSCs, NSCL61, bRiTs-G3, NFpp10-GBM, NS/CT-2A, SB28 and mGB2 mouse models.

\begin{tabular}{|c|c|c|c|c|c|c|c|c|}
\hline Model & Host & Induction & Histology & Immune Composition & Stem Cells & $\begin{array}{c}\text { Effect of } \\
\text { Standard-of-Care } \\
\text { Therapy }\end{array}$ & $\begin{array}{l}\text { Response to } \\
\text { Immunotherapy }\end{array}$ & Reference \\
\hline KR158B & C57BL/6 & $\begin{array}{c}\text { Spontaneous tumor } \\
\text { development in Nf1 and } \\
\text { p53 mutant mice }\end{array}$ & Secondary GBM & Not assessed & Not assessed & RT/TMZ: + & Resistance to ICB & $\begin{array}{c}\text { Reilly } 2000 \\
{[12,29,65,166-168]}\end{array}$ \\
\hline Mut3 & C57BL/6 & $\begin{array}{l}\text { Spontaneous tumor } \\
\text { development in Nf1, p53 } \\
\text { and Pten mutant mice }\end{array}$ & $\begin{array}{l}\text { GBM, high-grade } \\
\text { astrocytoma }\end{array}$ & $\begin{array}{l}\text { High levels of classical } \\
\text { and exhausted CD8 }{ }^{+} \mathrm{T} \\
\text { cells, } \mathrm{CD} 4^{+} \mathrm{T} \text { cells, Tregs } \\
\text { and resting microglia and } \\
\text { low levels of DC } \\
\text { infiltration }\end{array}$ & $\begin{array}{l}\text { Increased GFAP } \\
\text { and Nestin } \\
\text { expression }\end{array}$ & Not assessed & Not assessed & $\begin{array}{l}\text { Kwon } 2008 \\
{[33,169,170]}\end{array}$ \\
\hline 005 GSCs & C57BL/6 & $\begin{array}{l}\text { Transduction in } \\
\text { hippocampus of adult } \\
\text { mice with vectors with } \\
\text { activated HRas en AKT }\end{array}$ & $\begin{array}{c}\text { GBM, } \\
\text { heterogeneous }\end{array}$ & $\begin{array}{c}\text { Relatively } \\
\text { non-immunogenic, } \\
\text { absence of MHC-I and } \\
\text { down regulation of } \\
\text { co-stimulatory molecules, } \\
\text { limited T cell activation, } \\
\text { strong correlation with } \\
\text { human tumor immune } \\
\text { microenvironment }\end{array}$ & $\begin{array}{l}\text { Glioma stem cell } \\
\text { tumor model }\end{array}$ & Not assessed & Resistance to ICB & $\begin{array}{c}\text { Marumoto } 2008 \\
{[24,33,168,171-} \\
175]\end{array}$ \\
\hline NSCL61 & BALB/c & $\begin{array}{l}\text { HrasL61 overexpression } \\
\text { in p53 deficient neural } \\
\text { stem cells }\end{array}$ & $\begin{array}{c}\text { GBM, } \\
\text { heterogeneous }\end{array}$ & Not assessed & $\begin{array}{l}\text { Tumor model is } \\
\text { derived from } \\
\text { neural stem cells }\end{array}$ & Not assessed & $\begin{array}{c}\text { Generally positive } \\
\text { (limited amount of } \\
\text { data available) }\end{array}$ & $\begin{array}{l}\text { Hide } 2009 \\
{[27,68,72]}\end{array}$ \\
\hline bRiTs-G3 & C57BL/ 6 & $\begin{array}{l}\text { Overexpression of } \\
\text { HRasV12 in neural stem } \\
\text { cells from mice with } \\
\text { homozygous deletion of } \\
\text { the Ink4a/Arf locus }\end{array}$ & $\begin{array}{c}\text { GBM, } \\
\text { mesenchymal }\end{array}$ & Not assessed & $\begin{array}{l}\text { Tumor model is } \\
\text { derived from } \\
\text { neural stem cells }\end{array}$ & $\begin{array}{c}\text { RT: }+ \\
\text { RT resistance } \\
\text { develops after } \\
\text { repeated exposure }\end{array}$ & $\begin{array}{l}\text { Generally positive } \\
\text { (limited amount of } \\
\text { data available) }\end{array}$ & $\begin{array}{c}\text { Sampetrean } 2011 \\
{[28,68,176]}\end{array}$ \\
\hline $\begin{array}{l}\text { NFpp10- } \\
\text { GBM }\end{array}$ & C57BL/6 & $\begin{array}{c}\text { Embryonic stem cells } \\
\text { infected with shp53-shNf1 } \\
\text { and shPten lentiviral } \\
\text { vector }\end{array}$ & GBM & Lack of $\mathrm{T}$ cell infiltration & $\begin{array}{l}\text { Tumor model is } \\
\text { derived from } \\
\text { neural stem cells }\end{array}$ & Not assessed & Resistance to ICB & $\begin{array}{c}\text { Allen } 2017 \\
{[13,24,25,177]}\end{array}$ \\
\hline
\end{tabular}


Table 2. Cont.

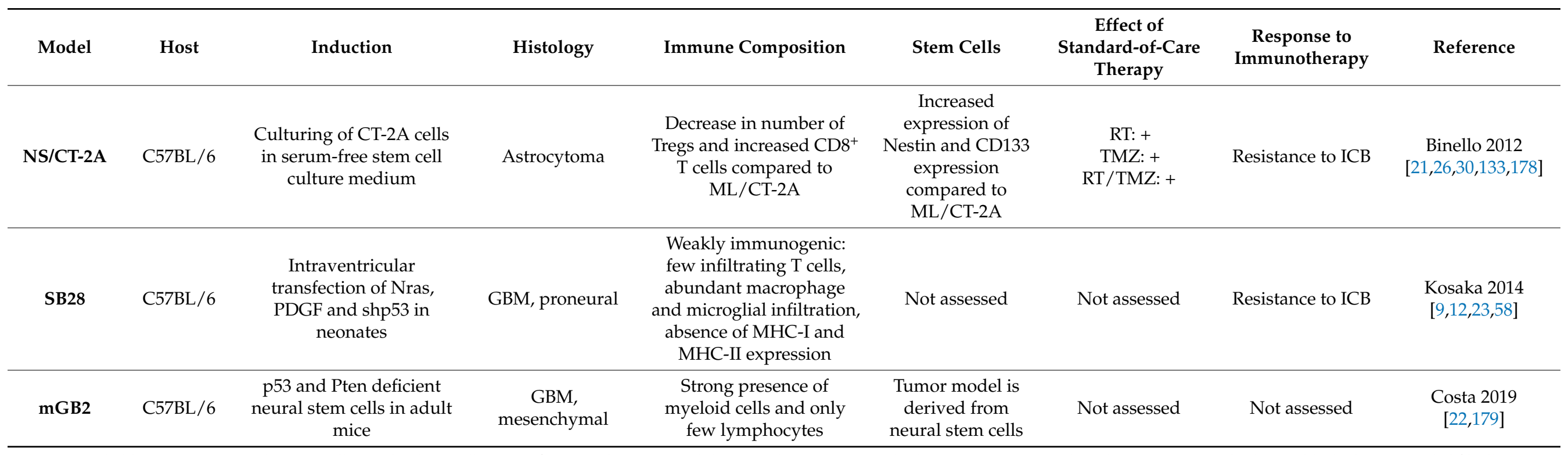

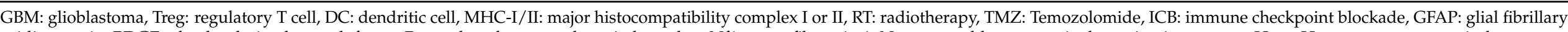

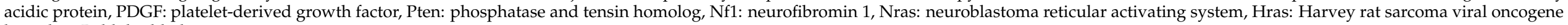
homolog. Bold: highlight. 


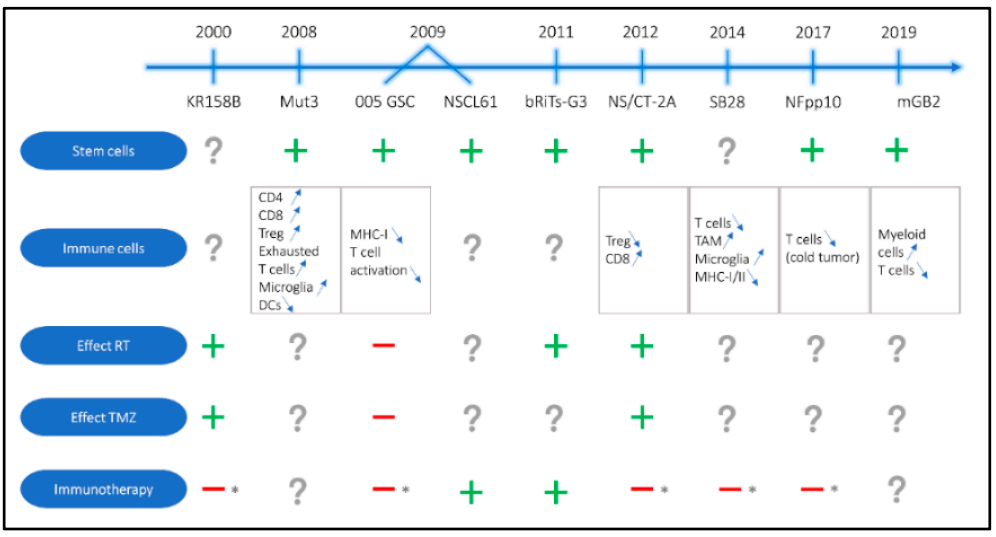

Figure 2. Schematic and chronological presentation of the more recent preclinical immunocompetent mouse models for glioblastoma with information about stemness, immune cell composition, the effects of standard of care and the efficiency of immunotherapy. RT: radiotherapy, TMZ: Temozolomide, Treg: regulatory T cell, DC: dendritic cell, MHC-I/II: major histocompatibility complex I or II, TAM: tumor associated macrophage, $(+)$ presence of stem cell populations and/or positive effect of treatment administration, (-) no effect of treatment administration, (?) data not available in literature and $\left({ }^{*}\right)$ resistance to immune checkpoint blockade.

\subsection{KR158B}

\subsubsection{Origins and Tumor Characteristics}

This mouse model was developed in 2000 by Reilly et al. and it is the first astrocytoma mouse model that was generated by knocking-down neurofibromin 1 (Nf1) and tumor protein p53 in mice which then spontaneously developed brain tumors with variable histology from low grade astrocytoma to GBM [29]. KR158B is the cell line derived from the most aggressive variants, which recapitulate the main features of human GBM [166]. To date, information on the immune and stemness characterization of this model is not available yet.

\subsubsection{Effect of Standard-of-Care}

The administration of whole brain irradiation and TMZ as single treatments wasn't able to positively affect survival in the KR158B model, and the combination of both resulted in a small median survival benefit of only five days, in line with results in the most aggressive human GBMs and making this a promising model for future preclinical research [166].

\subsubsection{Immunotherapeutic Approaches}

In the KR158B model, the combination of myeloablative conditioning, dendritic cell (DC) vaccination and adoptive cellular therapy resulted in a doubeling of the median survival and $30 \%$ of cured mice [166]. This model has also been used to test alternative TMZ treatment schedules in combination with immunotherapy $[65,167,168]$. The combination of TMZ and anti-PD-1 treatment has been shown to decrease the expression of T cell exhaustion markers. However, this had no effect on survival indicating that the model can develop resistance mechanisms to both these treatments [65]. However, the combined inhibition of PD-1 and C-C chemokine receptor type 2 (CCR2) lead to a synergistic effect and improved mouse survival, overvcoming the resistance to anti-PD-1 monotherapy [168]. The recent failure of clinical trials involving anti-PD-1 treatment [12] has demonstrated that human GBM are able to promote strong resistance mechanisms hampering the efficacy of checkpoint inhibitors. Therefore, performing preclinical research in models showing the same type of resistance, such as the KR158B, is of the utmost importance for an appropriate design of future clinical trials. 


\subsection{Mut3}

The Mut3 tumor model was developed by Kwon et al. [169] in 2008 by generating Nf1, p53 and Pten deficient mice which subsequently developed spontaneous high-grade astrocytomas. Neural stem cells (NSCs) from presymptomatic mice already showed aberrant stem cell features including higher proliferation levels, increased glial fibrillary acidic protein (GFAP) and increased Nestin expression [170]. The Mut3 cell line was generated by isolating the spontaneously developed tumors and bringing them in culture where they are maintained in neurosphere conditions [169]. Mut3 tumors are immunologically characterized by high levels of both classical and exhausted infiltrating $\mathrm{CD} 8^{+} \mathrm{T}$ cells, $\mathrm{CD} 4^{+}$ $\mathrm{T}$ cells, Tregs, and resting microglia, and by low levels of DC infiltration [33]. At this moment, no data is available on effects of standard-of-care or immunotherapeutics in the model.

\subsection{GSCs}

\subsubsection{Origins and Tumor Characteristics}

Marumoto et al. [24] developed this mouse model by injecting Cre-loxP-controlled lentiviral vectors expressing activated oncogenes AKT and Harvey-Ras in the hippocampus of GFAP-Cre Tp53+/ - mice. Subsequently, the obtained tumor cells were cultured as neurospheres and the 005 GSCs cell line was established [24,171]. Next, Saha et al. developed an immunocompetent model by reinjecting the 005 GSC cells in C57BL/ 6 mice $[172,173]$. 005 GSC-derived tumors show the same features as the primary tumor. Furthermore, 005 GSC cells express several stem cell markers such as Nestin, CD133 and Sox2 and proangiogenic vascular endothelial growth factor (VEGF) both in vitro and in vivo [173]. Even though RNA seq analysis performed by Khalsa et al. [33] showed that 005 GSC tumors exhibit a more immunologically active profile, Cheema et al. [173] described the tumors as non-immunogenic with the absence of major histocompatibility complex (MHC)-I expression and down regulation of co-stimulatory molecules. Nonetheless, Khalsa et al. showed that 005 GSC tumors had large amounts of activated and resting microglia and CD4 $4^{+}$Tregs, but low numbers of classical and exhausted $\mathrm{CD} 8^{+} \mathrm{T}$ cells [33]. This immunological phenotype strongly correlates with the immune microenvironment of GBM tumors in patients, making it a highly translational mouse model to be used for preclinical studies involving immunotherapeutic GBM research [33].

\subsubsection{Effect of Standard-of-Care}

Saha et al. [174] demonstrated that both low and high doses of TMZ treatment were ineffective in providing a survival benefit in the 005 GSC tumor model. In combination with OV, TMZ even counteracted the OVs positive effect on survival, indicating the chemoresistant nature of the 005 GSC tumor model and the importance of implementing standardof-care treatment in preclinical research. The effects of RT on 005 GSC tumors have not yet been described.

\subsubsection{Immunotherapeutic Approaches}

005 GSC model has experienced occasional use in immunotherapy research to evaluate the effect of combination treatments with OV, VEGF receptor (VEGFR) tyrosine kinase inhibitors (TKI) and immune checkpoint blockade [172,173,175]. Cheema et al. [173] showed the effect of a genetically engineered oncolytic HSV armed with IL-12 (G47 $\Delta$ mIL12). Median survival was prolonged after intratumoral injection of G47 $\Delta$-mIL12. Treatment with G47 $\Delta$-mIL12 doesn't only target GSCs but also increases IFN- $\gamma$ release, inhibits angiogenesis, and reduces the number of Tregs in the tumor [173]. The combination of G47 $\Delta$-mIL12 with the VEGFR TKI axitinib, anti-CTLA-4, anti-PD-1 or anti-PD-L1 further enhanced the positive effects on survival $[172,175]$ while monotherapy of checkpoint inhibition with anti-CTLA-4, anti-PD-1 or anti-PD-L1 only showed positive but modest effects [172]. Interestingly, a triple combination of G47 $\Delta$-mIL12 with anti-CTLA-4 and anti-PD-1 showed a synergistic curative effect that was accompanied with M1 macrophage 
polarization and an increased $\mathrm{CD} 8^{+} \mathrm{T}$ cell / Treg ratio [172]. Additionally, targeting myeloid-derived suppressor cells (MDSCs) by using a CCR2 antagonist was able to sensitize 005 GSC tumors to anti-PD-1 therapy [168].

\subsection{NSCL61}

\subsubsection{Origins and Tumor Characteristics}

The NSCL61 model was originally developed by Hide et al. [27] in 2009 by the overexpression of oncogenic Harvey rat sarcoma viral oncogene homolog (HRas) ${ }^{\mathrm{L} 61}$ in p53 deficient NSCs that subsequently formed tumors in nude mice after stereotactic injection. These tumors were grown in culture as the NSCL61 cells and consist of an heterogenous population of both glioma initiating and non-tumorigenic cells [27]. An immunocompetent tumor model can be established by injecting NSCL61 cells stereotactically in C57BL/6 mice [68]. An immunological evaluation of NSCL61 tumors has not yet been performed.

\subsubsection{Immunotherapeutic Approaches}

The NSCL61 has only been sparsly used in preclinical GBM research [68,72]. Tumor cell lysate-based vaccination therapy in combination with immunotherapy targeting CD40 resulted in the induction of IFN- $\gamma$ secretion from $\mathrm{CD}^{+} \mathrm{T}$ cells and prolonged survival [72]. The local delivery of anti-CD40 monoclonal antibodies resulted in an increased apoptosis, T cell infiltration and significantly prolonged survival in the NSCL61 and bRiTs-G3 model, but not in the GL261 model due to a lower CD40 expression [68].

\section{5. bRiTs-G3}

\subsubsection{Origins and Tumor Characteristics}

Sampetrean et al. [28] developed the bRiTs-G3 model in 2011 by retroviral transduction of constitutively active HRas ${ }^{\mathrm{V} 12}$ in normal neural stem/progenitor cells isolated from the subventricular zone of adult mice with a homozygous deletion of the Ink4a/Arf locus. Brain tumor-initiating cells were subsequently cultured as neurospheres. Molecular characterization of bRiTs-G3 tumors showed expression of mesenchymal and stem cell markers indicating a mesenchymal GBM subtype [28].

\subsubsection{Effect of Standard-of-Care}

The bRiTs-G3 tumor model was used to study resistance to RT by exposing the cells in vitro to repeated cycles of irradiation. After stereotactic injection of the pretreated cells, bRiTs-G3 tumors were resistant to subsequent treatment with RT, indicating the bRiTs-G3 cells acquire a radio-resistant phenotype after repeated exposure to irradiation [176].

\subsubsection{Immunotherapeutic Approaches}

When the bRiTs-G3 cells acquire their radioresistant phenotype, this also results in upregulation of insulin-like growth factor 1 receptor (IGF1R). Therefore, IGF1R blockade has been proposed as treatment option to prevent RT resistance and recurrence after RT [176]. Additionally, the bRiTs-G3 models has been used in immunotherapy research with anti-CD40 treatment where it significantly prolonged survival compared to control mice [68].

\subsection{NFpp10-GBM}

\subsubsection{Origins and Tumor Characteristics}

NFpp10-GBM cells were created in 2017 by infecting embryonic C57Bl/ 6 NSCs with lentiviral vectors containing shP53-shNF1 and shPten $[13,24,25]$. To date, this model has not yet been fully characterized and has only experienced very limited use in preclinical GBM research. 


\subsubsection{Immunotherapeutic Approaches}

The NFpp10-GBM model is mainly used to study tumor vasculature and angiogenesis $[13,177]$. The combination treatment of VEGF inhibition and anti-PD-L1 had no significant effect on survival. The ineffectiveness of the combination treatment was not due to the lack of PD-L1 expression of the cells, but rather the lack of T cell infiltration into the tumor [13]. To increase treatment efficacy a vascular targeting peptide (VTP) was developed containing the tumor necrosis factor (TNF) superfamily cytokine LIGHT which stimulates $\mathrm{T}$ cells, promotes vascular inflammation and is involved in lymph node neogenesis. Triple treatment with LIGHT-VTP, anti-VEGF and anti-PD-L1 resulted in a significantly reduced tumor burden as compared to untreated controls. Additionally, this combination treatment amplified high endothelial venules' frequency and T cell accumulation [177].

\subsection{NS/CT-2A}

\subsubsection{Origins and Tumor Characteristics}

As highlighted in the already mentioned review by Oh et al. [30], culturing CT-2A cells in neurospheres (NS/CT-2A) results in an increase of their stemness features. However, the difference in immunogenicity between CT-2A cells cultured in ML and NS was not described yet [26]. In a study performed by our group in 2019, NS/CT-2A tumors have been shown to induce a shorter survival and a higher expression of stemness and vascular markers compared with their ML counterpart. Furthermore, NS/CT-2A tumors showed an increase in $\mathrm{CD}^{+} \mathrm{T}$ cells and a decrease in the number of Tregs compared to ML/CT-2A tumors [133]. These features of the NS/CT-2A tumor model make it suitable for preclinical research aimed at developing therapeutic strategies against tumor stem cells and immune suppression.

\subsubsection{Effect of Standard-of-Care}

In the NS/CT-2A model, TMZ and stereotactic RT were able to prolong survival when administered as monotherapies or in combination. As monotherapy, stereotactic RT positively modulated both the adaptive and the innate immune system (increased CD ${ }^{+}$ T cells and decreased M2 macrophages and monocytic MDSCs (mMDSCs)) while TMZ only improved innate immunity (reduced mMDSCs) and to a lower extent than stereotactic RT [21]. Interestingly, the combination of these two treatments, despite prolonging survival, was immunologically detrimental compared to RT alone. This model was also used to assess the effects of stereotactic RT dose-escalation and dose-fractionation. RT doseescalation was associated with prolonged survival, improved anti-tumor immunity and reduced expression of stem cell markers. Conversely, RT dose-fractionation drastically reduced this positive effect [178]. Given the fact that GBM patients are currently treated with a fractionated RT schedule, these results highlight the need for studies aimed at identifying new RT schedules capable to induce a better immune modulation and a more efficient combination with immunotherapeutics.

\subsubsection{Immunotherapeutic Approaches}

As already mentioned, the combination of stereotactic RT and TMZ in the NS/CT2A model induced a less favorable immune microenvironment compared to RT alone. The model also appeared quite resistant to anti-PD-1 since this treatment could only induce minor modifications of survival and tumor immunity when administered alone or following RT-TMZ [21].

\subsection{SB28}

\subsubsection{Origins and Tumor Characteristics}

The SB28 cell line was developed by Kosaka et al. [23] via intraventricular injection of the oncogenes neuroblastoma reticular activating system (NRas), platelet-derived growth factor (PDGF) and short hairpin p53 in neonate C56BL/ 6 mice. Seven weeks following glioma induction, brain tissue was harvested, minced and seeded. The clone with the 
highest luciferase activity was selected and the SB28 cell-line was established [23]. There was an inverse correlation between the number of injected SB28 cells and the median survival [58]. The tumors can be classified as proneural, as indicated by the presence of PDGF alterations, and they are weakly immunogenic, as is the case for human GBMs [23, 58]. High cellularity of the tumor area, invasion of the normal brain parenchyma and areas of hypervascularization are also common characteristics of SB28 tumors and human GBM. Very few infiltrating $\mathrm{T}$ cells can be found, in contrast to abundant macrophage and microglial infiltration. Due to the absence of constitutive MHC-I and MHC-II expression, SB28 tumors are less susceptible of T cell immunosurveillance compared to GL261 tumors. SB28 tumors exhibit a very low mutational load (50-fold less than GL261 tumors), resulting in only a few neoepitopes and explaining the weak immunogenicity. The mutated genes were equally distributed across several pathways, but $10 \%$ of all mutations were found in the PDGF signaling pathway, confirming the proneural classification [58].

\subsubsection{Immunotherapeutic Approaches}

The use of combined anti-PD- 1 and anti-CTLA- 4 was curative in over 50\% of GL261 bearing mice, whereas it was ineffective in SB28 tumors [58]. This indicates that the SB28 model is more representative to human disease where immune checkpoint blockade provided unsatisfactory results so far $[9,12]$. Another study investigated the modulation of CD40 signaling and cyclooxygenase (COX)-2 blockade in the SB28 and GL261 models. The combination strategy promoted M1 cells, enhanced T cell effectors and prolonged survival [23].

\section{9. $m G B 2$}

The mGB2 tumor model was generated by Costa et al. [22] in 2019 by means of a double knockout (DKO) of Pten and p53 specifically in NSCs. Histopathological analysis of the developed tumors showed microvascular proliferation, necrotic areas and positivity for markers such as GFAP, oligodendrocyte transcription factor (OLIG2) and Ki67, all characteristics of human high-grade gliomas [22]. Subsequently, NSCs were isolated from the DKO mice and grown in culture. Reinjection of the cells in adult C57Bl/ 6 mice resulted in tumor induction 6-8 months later with a median survival of 170 days and with similar characteristics as the original tumor [22]. In order to try to reduce the survival time, tumor cells from a fully established invasive high-grade glioma (murine glioblastoma 0; mGB0) were isolated. Cells were serially implanted for two in vivo passages (mGB1 and mGB2) resulting in tumor development in all mice and a progressive shortening of the median survival. Based on genomic and transcriptomic data, $\mathrm{mGB} 0$ can be classified as the classical subtype, mGB1 as the proneural subtype and mGB2 as the mesenchymal subtype. mGB2 was selected as the most representative cell line compared to human disease with the worst prognosis and many histopathological features of high-grade gliomas. Also similar to what is observed in human GBMs, abundant myeloid cells and only few lymphocytes were found [179]. No therapies have been tested so far.

\section{Conclusions}

Immunocompetent mouse models are essential in preclinical GBM research, especially in the search for new immunotherapeutic strategies. When we compare all relevant mouse models based on their stemness, immune characteristics and response to standard-ofcare treatment, it is clear that there is not one mouse model that perfectly recapitulates the heterogeneity of a human GBM tumor. However, the overview we present here can help in deciding which model is best suited for which type of research. For instance, the translational impact of research involving immune checkpoint blockade might not be recommended for a mouse model such as GL261 that is very sensitive to this type of immunotherapy (which is not compatible with the clinical situation). A better choice would be to use mouse models that show a certain degree of resistance to immune checkpoint blockade such as KR158B, 005 GSC, Nfpp10-GBM or SB28. In addition, if we want to take 
into account any type of model-intrinsic response to certain treatments, it would be even better to evaluate new treatment modalities in multiple models. Furthermore, different tumor models might correlate to different patient populations of GBM. Therefore, the heterogeneity of GBM would be better addressed in preclinical research if a heterogeneous composition of tumor models is used. Interestingly, a recent study highlighted a variable response to immune checkpoint inhibitors in syngeneic mice inoculated with the same type of cells (GL261) [180]. If individual factors are relevant in a standardize situation such as a syngeneic model, it is reasonable to expect that they play a dramatic role in actual patients. For all these reasons, we believe that understanding and modelling patients heterogeneity in preclinical research will be one of the most relevant challenges in future preclinical research for GBM.

Another outstanding question relates to how the genomic aberrations of each tumor model correlate to aberrations in its microenvironment, and, even more importantly, how this compares to the human situation. Indeed, ongoing trials for targeted therapies are mainly based on genomic matching; however, the identification of those patient populations with similar immunologic features as observed in the mouse models is still lacking, but could be key in targeting the right approaches to the right patients.

Lastly, it is striking that only very few preclinical studies have incorporated the standard-of-care regimen when testing new treatments. Moreover, in the limited cases where standard-of-care is taken into account, this usually only consisted of RT and/or TMZ and rarely included a surgical resection of the tumor, nevertheless the corner stone of the clinical treatment. It is well known that GBMs at first diagnosis and at recurrence (therefore, after the whole standard of care treatment) harbor important differences in term of molecular features and druggable targets [181]. In this view, it is of paramount importance to integrate in the pipeline of preclinical studies surgery, focal radiotherapy and TMZ-based chemotherapy in order to model such longitudinal neoplastic evolution. A paradigm shift is necessary: preclinical research should not only be aimed at discovering new treatments, but also at identifying the most appropriate momentum for their administration in order to maximize their effect in synergy with standard therapies.

Author Contributions: Conceptualization, M.R. and A.C.; methodology, S.B.; investigation, S.B., R.W. and F.D.S.; writing — original draft preparation, S.B. and R.W.; writing—review and editing, M.R., A.C. and F.D.S.; visualization, M.R. and R.W.; supervision, A.C.; project administration, A.C.; funding acquisition, A.C. All authors have read and agreed to the published version of the manuscript.

Funding: This research received no external funding.

Conflicts of Interest: The authors declare no conflict of interest.

\section{References}

1. Cloughesy, T.F.; Mochizuki, A.Y.; Orpilla, J.R.; Hugo, W.; Lee, A.H.; Davidson, T.B.; Wang, A.C.; Ellingson, B.M.; Rytlewski, J.A.; Sanders, C.M.; et al. Neoadjuvant anti-PD-1 immunotherapy promotes a survival benefit with intratumoral and systemic immune responses in recurrent glioblastoma. Nat. Med. 2019, 25, 477-486. [CrossRef] [PubMed]

2. Bianco, J.; Bastiancich, C.; Jankovski, A.; Rieux, A.D.; Préat, V.; Danhier, F. On glioblastoma and the search for a cure: Where do we stand? Cell. Mol. Life Sci. 2017, 74, 2451-2466. [CrossRef] [PubMed]

3. Prados, M.D.; Byron, S.A.; Tran, N.L.; Phillips, J.J.; Molinaro, A.M.; Ligon, K.L.; Wen, P.Y.; Kuhn, J.G.; Mellinghoff, I.K.; de Groot, J.F.; et al. Toward precision medicine in glioblastoma: The promise and the challenges. Neuro. Oncol. 2015, 17, 1051-1063. [CrossRef]

4. Jackson, C.M.; Choi, J.; Lim, M. Mechanisms of immunotherapy resistance: Lessons from glioblastoma. Nat. Immunol. 2019, 20, 1100-1109. [CrossRef] [PubMed]

5. Ostrom, Q.T.; Bauchet, L.; Davis, F.G.; Deltour, I.; Fisher, J.L.; Langer, C.E.; Pekmezci, M.; Schwartzbaum, J.A.; Turner, M.C.; Walsh, K.M.; et al. The epidemiology of glioma in adults: A state of the science review. Neuro-Oncol. 2014, 16, 896-913. [CrossRef]

6. Bagley, S.J.; Desai, A.S.; Linette, G.P.; June, C.H.; O'Rourke, D.M. CAR T-cell therapy for glioblastoma: Recent clinical advances and future challenges. Neuro. Oncol. 2018, 20,1429-1438. [CrossRef]

7. Wang, J.; Shen, F.; Yao, Y.; Wang, L.L.; Zhu, Y.; Hu, J. Adoptive Cell Therapy: A Novel and Potential Immunotherapy for Glioblastoma. Front. Oncol. 2020, 10, 59. [CrossRef] 
8. Lim, M.; Xia, Y.; Bettegowda, C.; Weller, M. Current state of immunotherapy for glioblastoma. Nat. Rev. Clin. Oncol. 2018, 15, 422-442. [CrossRef]

9. Liau, L.M.; Ashkan, K.; Tran, D.D.; Campian, J.L.; Trusheim, J.E.; Cobbs, C.S.; Heth, J.A.; Salacz, M.; Taylor, S.; D'Andre, S.D.; et al. First results on survival from a large Phase 3 clinical trial of an autologous dendritic cell vaccine in newly diagnosed glioblastoma. J. Transl. Med. 2018, 16, 142. [CrossRef]

10. Wen, P.Y.; Reardon, D.A.; Armstrong, T.S.; Phuphanich, S.; Aiken, R.D.; Landolfi, J.C.; Curry, W.T.; Zhu, J.J.; Glantz, M.; Peereboom, D.M.; et al. A randomized double-blind placebo-controlled phase II trial of dendritic cell vaccine ICT-107 in newly diagnosed patients with glioblastoma. Clin. Cancer Res. 2019, 25, 5799-5807. [CrossRef]

11. Sprooten, J.; Ceusters, J.; Coosemans, A.; Agostinis, P.; De Vleeschouwer, S.; Zitvogel, L.; Kroemer, G.; Galluzzi, L.; Garg, A.D. Trial watch: Dendritic cell vaccination for cancer immunotherapy. Oncoimmunology 2019, 8, 1638212. [CrossRef]

12. Reardon, D.A.; Brandes, A.A.; Omuro, A.; Mulholland, P.; Lim, M.; Wick, A.; Baehring, J.; Ahluwalia, M.S.; Roth, P.; Bähr, O.; et al Effect of Nivolumab vs Bevacizumab in Patients with Recurrent Glioblastoma: The CheckMate 143 Phase 3 Randomized Clinical Trial. JAMA Oncol. 2020, 6, 1003-1010. [CrossRef] [PubMed]

13. Allen, E.; Jabouille, A.; Rivera, L.B.; Lodewijckx, I.; Missiaen, R.; Steri, V.; Feyen, K.; Tawney, J.; Hanahan, D.; Michael, I.P.; et al. Combined antiangiogenic and anti-PD-L1 therapy stimulates tumor immunity through HEV formation. Sci. Transl. Med. 2017, 9, eaak9679. [CrossRef]

14. Verreault, M.; Schmitt, C.; Goldwirt, L.; Pelton, K.; Haidar, S.; Levasseur, C.; Guehennec, J.; Knoff, D.; Labussière, M.; Marie, Y.; et al. Preclinical efficacy of the MDM2 inhibitor RG7112 in MDM2-amplified and TP53 wild-type glioblastomas. Clin. Cancer Res. 2016, 22, 1185-1196. [CrossRef] [PubMed]

15. Wu, A.; Maxwell, R.; Xia, Y.; Cardarelli, P.; Oyasu, M.; Belcaid, Z.; Kim, E.; Hung, A.; Luksik, A.S.; Garzon-Muvdi, T.; et al. Combination anti-CXCR4 and anti-PD-1 immunotherapy provides survival benefit in glioblastoma through immune cell modulation of tumor microenvironment. J. Neurooncol. 2019, 143, 241-249. [CrossRef]

16. Gupta, S.K.; Kizilbash, S.H.; Carlson, B.L.; Mladek, A.C.; Boakye-Agyeman, F.; Bakken, K.K.; Pokorny, J.L.; Schroeder, M.A.; Decker, P.A.; Cen, L.; et al. Delineation of MGMT Hypermethylation as a Biomarker for Veliparib-Mediated TemozolomideSensitizing Therapy of Glioblastoma. J. Natl. Cancer Inst. 2016, 108, 1-10. [CrossRef]

17. Zahonero, C.; Aguilera, P.; Ramírez-Castillejo, C.; Pajares, M.; Bolós, M.V.; Cantero, D.; Perez-Nuñez, A.; Hernández-Laín, A.; Sánchez-Gómez, P.; Sepúlveda, J.M. Preclinical test of dacomitinib, an irreversible EGFR inhibitor, confirms its effectiveness for glioblastoma. Mol. Cancer Ther. 2015, 14, 1548-1558. [CrossRef]

18. Guishard, A.F.; Yakisich, J.S.; Azad, N.; Iyer, A.K.V. Translational gap in ongoing clinical trials for glioma. J. Clin. Neurosci. 2018, 47, 28-42. [CrossRef]

19. Coosemans, A.; Vankerckhoven, A.; Baert, T.; Boon, L.; Ruts, H.; Riva, M.; Blagden, S.; Delforge, M.; Concin, N.; Mirza, M.R.; et al. Combining conventional therapy with immunotherapy: A risky business? Eur. J. Cancer 2019, 113, 41-44. [CrossRef]

20. Kumar-Sinha, C.; Chinnaiyan, A.M. Precision oncology in the age of integrative genomics. Nat. Biotechnol. 2018, 36, 46-60. [CrossRef]

21. Riva, M.; Wouters, R.; Sterpin, E.; Giovannoni, R.; Boon, L.; Himmelreich, U.; Gsell, W.; Van Ranst, M.; Coosemans, A. Radiotherapy, Temozolomide and anti-programmed cell death protein 1 treatments modulate the immune microenvironment in experimental high-grade glioma. Neurosurgery 2020. [CrossRef] [PubMed]

22. Costa, B.; Eisemann, T.; Strelau, J.; Spaan, I.; Korshunov, A.; Liu, H.K.; Bugert, P.; Angel, P.; Peterziel, H. Intratumoral platelet aggregate formation in a murine preclinical glioma model depends on podoplanin expression on tumor cells. Blood Adv. 2019, 3, 1092-1102. [CrossRef] [PubMed]

23. Kosaka, A.; Ohkuri, T.; Okada, H. Combination of an agonistic anti-CD40 monoclonal antibody and the COX-2 inhibitor celecoxib induces anti-glioma effects by promotion of type-1 immunity in myeloid cells and T-cells. Cancer Immunol. Immunother. 2014, 63, 847-857. [CrossRef] [PubMed]

24. Marumoto, T.; Tashiro, A.; Friedmann-morvinski, D.; Soda, Y.; Gage, F.H.; Verma, I.M. Development of a novel mouse glioma model using lentiviral vectors. Nat. Med. 2009, 15, 110-116. [CrossRef]

25. Friedmann-Morvinski, D.; Bushong, E.A.; Ke, E.; Soda, Y.; Marumoto, T.; Singer, O.; Ellisman, M.H.; Verma, I.M. Dedifferentiation of Neurons and Astrocytes by Oncogenes Can Induce Gliomas in Mice. Science 2012, 338, 1080-1084. [CrossRef]

26. Binello, E.; Qadeer, Z.A.; Kothari, H.P.; Emdad, L.; Germano, I.M. Stemness of the CT-2A immunocompetent mouse brain tumor model: Characterization in vitro. J. Cancer 2012, 3, 166-174. [CrossRef]

27. Hide, T.; Takezaki, T.; Nakatani, Y.; Nakamura, H.; Kuratsu, J.I.; Kondo, T. Sox11 prevents tumorigenesis of glioma-initiating cells by inducing neuronal differentiation. Cancer Res. 2009, 69, 7953-7959. [CrossRef]

28. Sampetrean, O.; Saga, I.; Nakanishi, M.; Sugihara, E.; Fukaya, R.; Onishi, N.; Osuka, S.; Akahata, M.; Kai, K.; Sugimoto, H.; et al. Invasion precedes tumor mass formation in a malignant brain tumor model of genetically modified neural stem cells. Neoplasia 2011, 13, 784-791. [CrossRef]

29. Reilly, K.M.; Loisel, D.A.; Bronson, R.T.; McLaughlin, M.E.; Jacks, T. Nf1;Trp53 mutant mice develop glioblastoma with evidence of strain-specific effects. Nat. Genet. 2000, 26, 109-113. [CrossRef]

30. Oh, T.; Fakurnejad, S.; Sayegh, E.T.; Clark, A.J.; Ivan, M.E.; Sun, M.Z.; Safaee, M.; Bloch, O.; James, C.D.; Parsa, A.T. Immunocompetent murine models for the study of glioblastoma immunotherapy. J. Transl. Med. 2014, 12, 107. [CrossRef] 
31. Wu, A.; Oh, S.; Wiesner, S.M.; Ericson, K.; Chen, L.; Hall, W.A.; Champoux, P.E.; Low, W.C.; Ohlfest, J.R. Persistence of CD133+ cells in human and mouse glioma cell lines: Detailed characterization of GL261 glioma cells with cancer stem cell-like properties. Stem Cells Dev. 2008, 17, 173-184. [CrossRef] [PubMed]

32. Behnan, J.; Isakson, P.; Joel, M.; Cilio, C.; Langmoen, I.A.; Vik-Mo, E.O.; Badn, W. Recruited brain tumor-derived mesenchymal stem cells contribute to brain tumor progression. Stem Cells 2014, 32, 1110-1123. [CrossRef] [PubMed]

33. Khalsa, J.K.; Cheng, N.; Keegan, J.; Chaudry, A.; Driver, J.; Bi, W.L.; Lederer, J.; Shah, K. Immune phenotyping of diverse syngeneic murine brain tumors identifies immunologically distinct types. Nat. Commun. 2020, 11, 3912. [CrossRef] [PubMed]

34. Miller, I.S.; Didier, S.; Murray, D.W.; Turner, T.H.; Issaivanan, M.; Ruggieri, R.; Al-Abed, Y.; Symons, M. Semapimod sensitizes glioblastoma tumors to ionizing radiation by targeting microglia. PLoS ONE 2014, 9, e95885. [CrossRef] [PubMed]

35. Tran, T.A.T.; Kim, Y.H.; Duong, T.H.; Jung, S.; Kim, I.Y.; Moon, K.S.; Jang, W.Y.; Lee, H.J.; Lee, J.J.; Jung, T.Y. Peptide Vaccine Combined Adjuvants Modulate Anti-tumor Effects of Radiation in Glioblastoma Mouse Model. Front. Immunol. 2020, 11, 1165. [CrossRef]

36. Durant, S.T.; Zheng, L.; Wang, Y.; Chen, K.; Zhang, L.; Zhang, T.; Yang, Z.; Riches, L.; Trinidad, A.G.; Fok, J.H.L.; et al. The brain-penetrant clinical ATM inhibitor AZD1390 radiosensitizes and improves survival of preclinical brain tumor models. Sci. Adv. 2018, 4, eaat1719. [CrossRef]

37. Zeng, J.; See, A.P.; Phallen, J.; Jackson, C.M.; Belcaid, Z.; Ruzevick, J.; Durham, N.; Meyer, C.; Harris, T.J.; Albesiano, E.; et al. Anti-PD-1 blockade and stereotactic radiation produce long-term survival in mice with intracranial gliomas. Int. J. Radiat. Oncol. Biol. Phys. 2013, 86, 343-349. [CrossRef]

38. Dai, B.; Qi, N.; Li, J.; Zhang, G. Temozolomide combined with PD-1 Antibody therapy for mouse orthotopic glioma model. Biochem. Biophys. Res. Commun. 2018, 501, 871-876. [CrossRef]

39. Ferrer-Font, L.; Arias-Ramos, N.; Lope-Piedrafita, S.; Julià-Sapé, M.; Pumarola, M.; Arús, C.; Candiota, A.P. Metronomic treatment in immunocompetent preclinical GL261 glioblastoma: Effects of cyclophosphamide and temozolomide. NMR Biomed. 2017, 30, e3748. [CrossRef]

40. Hanihara, M.; Kawataki, T.; Oh-Oka, K.; Mitsuka, K.; Nakao, A.; Kinouchi, H. Synergistic antitumor effect with indoleamine 2,3-dioxygenase inhibition and temozolomide in a murine glioma model. J. Neurosurg. 2016, 124, 1594-1601. [CrossRef]

41. Malo, C.S.; Renner, D.N.; Huseby Kelcher, A.M.; Jin, F.; Hansen, M.J.; Pavelko, K.D.; Johnson, A.J. The effect of vector silencing during picornavirus vaccination against experimental melanoma and glioma. PLoS ONE 2016, 11, e0162064. [CrossRef] [PubMed]

42. Bu, N.; Wu, H.; Zhang, G.; Zhan, S.; Zhang, R.; Sun, H.; Du, Y.; Yao, L.; Wang, H. Exosomes from Dendritic Cells Loaded with Chaperone-Rich Cell Lysates Elicit a Potent T Cell Immune Response Against Intracranial Glioma in Mice. J. Mol. Neurosci. 2015, 56, 631-643. [CrossRef]

43. Yan, Y.; Fang, M.; Xuan, W.; Wu, X.; Meng, X.; Wang, L.; Yu, Y. The therapeutic potency of HSP65-GTL in GL261 Glioma-bearing Mice. J. Immunother. 2015, 38, 341-349. [CrossRef] [PubMed]

44. Durant, S.T.; Zheng, L.; Wang, Y.; Chen, K.; Zhang, L.; Zhang, T.; Yang, Z.; Riches, L.; Trinidad, A.G.; Fok, J.H.; et al. Survivin Monoclonal Antibodies Detect Survivin Cell Surface Expression and Inhibit Tumor Growth in vivo. Clin. Cancer Res. 2018, 176, 139-148.

45. Chen, M.; Sun, R.; Shi, B.; Wang, Y.; Di, S.; Luo, H.; Sun, Y.; Li, Z.; Zhou, M.; Jiang, H. Antitumor efficacy of chimeric antigen receptor T cells against EGFRvIII-expressing glioblastoma in C57BL/6 mice. Biomed. Pharmacother. 2019, 113, 108734. [CrossRef]

46. Cockle, J.V.; Rajani, K.; Zaidi, S.; Kottke, T.; Thompson, J.; Diaz, R.M.; Shim, K.; Peterson, T.; Parney, I.F.; Short, S.; et al. Combination viroimmunotherapy with checkpoint inhibition to treat glioma, based on location-specific tumor profiling. Neuro. Oncol. 2016, 18, 518-527. [CrossRef]

47. Jiang, H.; Clise-Dwyer, K.; Ruisaard, K.E.; Fan, X.; Tian, W.; Gumin, J.; Lamfers, M.L.; Kleijn, A.; Lang, F.F.; Yung, W.K.; et al. Delta-24-RGD oncolytic adenovirus elicits anti-glioma immunity in an immunocompetent mouse model. PLoS ONE 2014, 9, e97407. [CrossRef]

48. Tang, B.; Guo, Z.S.; Bartlett, D.L.; Yan, D.Z.; Schane, C.P.; Thomas, D.L.; Liu, J.; McFadden, G.; Shisler, J.L.; Roy, E.J. Synergistic Combination of Oncolytic Virotherapy and Immunotherapy for Glioma. Clin. Cancer Res. 2020, 26, 2216-2230. [CrossRef]

49. Koks, C.A.; Garg, A.D.; Ehrhardt, M.; Riva, M.; Vandenberk, L.; Boon, L.; De Vleeschouwer, S.; Agostinis, P.; Graf, N.; Van Gool, S.W. Newcastle disease virotherapy induces long-term survival and tumor-specific immune memory in orthotopic glioma through the induction of immunogenic cell death. Int. J. Cancer 2015, 136, E313-E325. [CrossRef]

50. Kleijn, A.; van den Bossche, W.; Haefner, E.S.; Belcaid, Z.; Burghoorn-Maas, C.; Kloezeman, J.J.; Pas, S.D.; Leenstra, S.; Debets, R.; de Vrij, J.; et al. The Sequence of Delta24-RGD and TMZ Administration in Malignant Glioma Affects the Role of CD8+T Cell Anti-tumor Activity. Mol. Ther. Oncolytics 2017, 5, 11-19. [CrossRef]

51. Zhu, S.; Lv, X.; Zhang, X.; Li, T.; Zang, G.; Yang, N.; Wang, X.; Wu, J.; Chen, W.; Liu, Y.J.; et al. An effective dendritic cell-based vaccine containing glioma stem-like cell lysate and $\mathrm{CpG}$ adjuvant for an orthotopic mouse model of glioma. Int. J. Cancer 2019, 144, 2867-2879. [CrossRef] [PubMed]

52. Hardcastle, J.; Mills, L.; Malo, C.S.; Jin, F.; Kurokawa, C.; Geekiyanage, H.; Schroeder, M.; Sarkaria, J.; Johnson, A.J.; Galanis, E. Immunovirotherapy with measles virus strains in combination with anti-PD-1 antibody blockade enhances antitumor activity in glioblastoma treatment. Neuro. Oncol. 2017, 19, 493-502. [CrossRef] [PubMed] 
53. Jahan, N.; Talat, H.; Alonso, A.; Saha, D.; Curry, W.T. Triple combination immunotherapy with GVAX, anti-PD-1 monoclonal antibody, and agonist anti-OX40 monoclonal antibody is highly effective against murine intracranial glioma. Oncoimmunology 2019, 8, e1577108. [CrossRef] [PubMed]

54. Patel, M.A.; Kim, J.E.; Theodros, D.; Tam, A.; Velarde, E.; Kochel, C.M.; Francica, B.; Nirschl, T.R.; Ghasemzadeh, A.; Mathios, D.; et al. Agonist anti-GITR monoclonal antibody and stereotactic radiation induce immune-mediated survival advantage in murine intracranial glioma. J. Immunother. Cancer 2016, 4, 28. [CrossRef] [PubMed]

55. Belcaid, Z.; Phallen, J.A.; Zeng, J.; See, A.P.; Mathios, D.; Gottschalk, C.; Nicholas, S.; Kellett, M.; Ruzevick, J.; Jackson, C.; et al. Focal radiation therapy combined with 4-1BB activation and CTLA-4 blockade yields long-term survival and a protective antigen-specific memory response in a murine glioma model. PLoS ONE 2014, 9, e101764. [CrossRef] [PubMed]

56. Hung, A.L.; Maxwell, R.; Theodros, D.; Belcaid, Z.; Mathios, D.; Luksik, A.S.; Kim, E.; Wu, A.; Xia, Y.; Garzon-Muvdi, T.; et al. TIGIT and PD-1 dual checkpoint blockade enhances antitumor immunity and survival in GBM. Oncoimmunology 2018, 7, e1466769. [CrossRef]

57. Kim, J.E.; Patel, M.A.; Mangraviti, A.; Kim, E.S.; Theodros, D.; Velarde, E.; Liu, A.; Sankey, E.W.; Tam, A.; Xu, H.; et al. Combination Therapy with Anti-PD-1, Anti-TIM-3, and Focal Radiation Results in Regression of Murine Gliomas. Clin. Cancer Res. 2017, 23, 124-136. [CrossRef]

58. Genoud, V.; Marinari, E.; Nikolaev, S.I.; Castle, J.C.; Bukur, V.; Dietrich, P.Y.; Okada, H.; Walker, P.R. Responsiveness to anti-PD-1 and anti-CTLA-4 immune checkpoint blockade in SB28 and GL261 mouse glioma models. Oncoimmunology 2018, 7, e1501137. [CrossRef]

59. Qian, J.; Wang, C.; Wang, B.; Yang, J.; Wang, Y.; Luo, F.; Xu, J.; Zhao, C.; Liu, R.; Chu, Y. The IFN- $\gamma /$ PD-L1 axis between T cells and tumor microenvironment: Hints for glioma anti-PD-1/PD-L1 therapy. J. Neuroinflamm. 2018, 15, 290. [CrossRef]

60. Garg, A.D.; Vandenberk, L.; Van Woensel, M.; Belmans, J.; Schaaf, M.; Boon, L.; De Vleeschouwer, S.; Agostinis, P. Preclinical efficacy of immune-checkpoint monotherapy does not recapitulate corresponding biomarkers-based clinical predictions in glioblastoma. Oncoimmunology 2017, 6, e1295903. [CrossRef]

61. Shevtsov, M.; Pitkin, E.; Ischenko, A.; Stangl, S.; Khachatryan, W.; Galibin, O.; Edmond, S.; Lobinger, D.; Multhoff, G. Ex vivo Hsp70-activated NK cells in combination with PD-1 inhibition significantly increase overall survival in preclinical models of glioblastoma and lung cancer. Front. Immunol. 2019, 10, 454. [CrossRef] [PubMed]

62. Kim, J.W.; Kane, J.R.; Panek, W.K.; Young, J.S.; Rashidi, A.; Yu, D.; Kanojia, D.; Hasan, T.; Miska, J.; Gómez-Lim, M.A.; et al. A Dendritic Cell-Targeted Adenoviral Vector Facilitates Adaptive Immune Response Against Human Glioma Antigen (CMV-IE) and Prolongs Survival in a Human Glioma Tumor Model. Neurotherapeutics 2018, 15, 1127-1138. [CrossRef] [PubMed]

63. Maggio, D.; Ho, W.S.; Breese, R.; Walbridge, S.; Wang, H.; Cui, J.; Heiss, J.D.; Gilbert, M.R.; Kovach, J.S.; Lu, R.O.; et al. Inhibition of protein phosphatase-2A with LB-100 enhances antitumor immunity against glioblastoma. J. Neurooncol. 2020, 148, 231-244. [CrossRef] [PubMed]

64. Mathios, D.; Park, C.K.; Marcus, W.D.; Alter, S.; Rhode, P.R.; Jeng, E.K.; Wong, H.C.; Pardoll, D.M.; Lim, M. Therapeutic administration of IL-15 superagonist complex ALT-803 leads to long-term survival and durable antitumor immune response in a murine glioblastoma model. Int. J. Cancer 2016, 138, 187-194. [CrossRef] [PubMed]

65. Karachi, A.; Yang, C.; Dastmalchi, F.; Sayour, E.J.; Huang, J.; Azari, H.; Long, Y.; Flores, C.; Mitchell, D.A.; Rahman, M. Modulation of temozolomide dose differentially affects T-cell response to immune checkpoint inhibition. Neuro. Oncol. 2019, 21, 730-741. [CrossRef] [PubMed]

66. Li, J.; Liu, X.; Duan, Y.; Liu, Y.; Wang, H.; Lian, S.; Zhuang, G.; Fan, Y. Combined blockade of Ts cell immunoglobulin and mucin domain 3 and carcinoembryonic antigen-related cell adhesion molecule 1 results in durable therapeutic efficacy in mice with intracranial gliomas. Med. Sci. Monit. 2017, 23, 3593-3602. [CrossRef]

67. Jahan, N.; Talat, H.; Curry, W.T. Agonist OX40 immunotherapy improves survival in glioma-bearing mice and is complementary with vaccination with irradiated GM-CSF-expressing tumor cells. Neuro. Oncol. 2018, 20, 44-54. [CrossRef] [PubMed]

68. Shoji, T.; Saito, R.; Chonan, M.; Shibahara, I.; Sato, A.; Kanamori, M.; Sonoda, Y.; Kondo, T.; Ishii, N.; Tominaga, T. Local convection-enhanced delivery of an anti-CD40 agonistic monoclonal antibody induces antitumor effects in mouse glioma models. Neuro. Oncol. 2016, 18, 1120-1128. [CrossRef]

69. Eberstå, S.; Sandén, E.; Fritzell, S.; Darabi, A.; Visse, E.; Siesjö, P. Intratumoral COX-2 inhibition enhances GM-CSF immunotherapy against established mouse GL261 brain tumors. Int. J. Cancer 2014, 134, 2748-2753. [CrossRef]

70. Miska, J.; Rashidi, A.; Chang, A.L.; Muroski, M.E.; Han, Y.; Zhang, L.; Lesniak, M.S. Anti-GITR therapy promotes immunity against malignant glioma in a murine model. Cancer Immunol. Immunother. 2016, 65, 1555-1567. [CrossRef]

71. Zheng, H.; Yang, B.; Xu, D.; Wang, W.; Tan, J.; Sun, L.; Li, Q.; Sun, L.; Xia, X. Induction of specific T helper-9 cells to inhibit glioma cell growth. Oncotarget 2017, 8, 4864-4874. [CrossRef] [PubMed]

72. Chonan, M.; Saito, R.; Shoji, T.; Shibahara, I.; Kanamori, M.; Sonoda, Y.; Watanabe, M.; Kikuchi, T.; Ishii, N.; Tominaga, T. CD40/CD40L expression correlates with the survival of patients with glioblastomas and an augmentation in CD40 signaling enhances the efficacy of vaccinations against glioma models. Neuro. Oncol. 2015, 17, 1453-1462. [CrossRef] [PubMed]

73. Vandenberk, L.; Garg, A.D.; Verschuere, T.; Koks, C.; Belmans, J.; Beullens, M.; Agostinis, P.; De Vleeschouwer, S.; Van Gool, S.W. Irradiation of necrotic cancer cells, employed for pulsing dendritic cells (DCs), potentiates DC vaccine-induced antitumor immunity against high-grade glioma. Oncoimmunology 2016, 5, e1083669. [CrossRef] [PubMed] 
74. Moertel, C.L.; Xia, J.; LaRue, R.; Waldron, N.N.; Andersen, B.M.; Prins, R.M.; Okada, H.; Donson, A.M.; Foreman, N.K.; Hunt, M.A.; et al. CD200 in CNS tumor-induced immunosuppression: The role for CD200 pathway blockade in targeted immunotherapy. J. Immunother. Cancer 2014, 2, 46. [CrossRef] [PubMed]

75. Jordan, M.; Waxman, D.J. CpG-1826 immunotherapy potentiates chemotherapeutic and anti-tumor immune responses to metronomic cyclophosphamide in a preclinical glioma model. Physiol. Behav. 2018, 176, 139-148. [CrossRef] [PubMed]

76. Zhang, Y.; Luo, F.; Li, A.; Qian, J.; Yao, Z.; Feng, X.; Chu, Y. Systemic injection of TLR1/2 agonist improves adoptive antigenspecific $T$ cell therapy in glioma-bearing mice. Clin. Immunol. 2014, 154, 26-36. [CrossRef]

77. Ladomersky, E.; Zhai, L.; Lauing, K.L.; Bell, A.; Xu, J.; Kocherginsky, M.; Zhang, B.; Wu, J.D.; Podojil, J.R.; Platanias, L.C.; et al. Advanced Age Increases Immunosuppression in the Brain and Decreases Immunotherapeutic Efficacy in Subjects with Glioblastoma. Clin. Cancer Res. 2020, 26, 5232-5245. [CrossRef]

78. Azambuja, J.H.; da Silveira, E.F.; de Carvalho, T.R.; Oliveira, P.S.; Pacheco, S.; do Couto, C.T.; Beira, F.T.; Stefanello, F.M.; Spanevello, R.M.; Braganhol, E. Glioma sensitive or chemoresistant to temozolomide differentially modulate macrophage protumor activities. Biochim. Biophys. Acta Gen. Subj. 2017, 1861, 2652-2662. [CrossRef]

79. Wu, S.; Calero-Pérez, P.; Villamañan, L.; Arias-Ramos, N.; Pumarola, M.; Ortega-Martorell, S.; Julià-Sapé, M.; Arús, C.; Candiota, A.P. Anti-tumour immune response in GL261 glioblastoma generated by Temozolomide Immune-Enhancing Metronomic Schedule monitored with MRSI-based nosological images. NMR Biomed. 2020, 33, e4229. [CrossRef]

80. Dey, M.; Chang, A.L.; Miska, J.; Wainwright, D.A.; Ahmed, A.U.; Balyasnikova, I.V.; Pytel, P.; Han, Y.; Tobias, A.; Zhang, L.; et al. Dendritic Cell-Based Vaccines that Utilize Myeloid Rather than Plasmacytoid Cells Offer a Superior Survival Advantage in Malignant Glioma. Physiol. Behav. 2017, 176, 139-148. [CrossRef]

81. Kindy, M.S.; Yu, J.; Zhu, H.; Smith, M.T.; Gattoni-Celli, S. A therapeutic cancer vaccine against GL261 murine glioma. J. Transl. Med. 2016, 14, 1-9. [CrossRef] [PubMed]

82. Dong, B.; Wang, L.; Nie, S.; Li, X.; Xiao, Y.; Yang, L.; Meng, X.; Zhao, P.; Cui, C.; Tu, L.; et al. Anti-glioma effect of intracranial vaccination with tumor cell lysate plus flagellin in mice. Vaccine 2018, 36, 8148-8157. [CrossRef]

83. Renner, D.N.; Jin, F.; Litterman, A.J.; Balgeman, A.J.; Hanson, L.M.; Gamez, J.D.; Chae, M.; Carlson, B.L.; Sarkaria, J.N.; Parney, I.F.; et al. Effective treatment of established GL261 murine gliomas through picornavirus vaccination-enhanced tumor antigen-specific CD8+ T cell responses. PLoS ONE 2015, 10, e0125565. [CrossRef] [PubMed]

84. Gattoni-Celli, S.; Young, M.R.I. Restoration of immune responsiveness to glioma by vaccination of mice with established brain gliomas with a semi-allogeneic vaccine. Int. J. Mol. Sci. 2016, 17, 1465. [CrossRef] [PubMed]

85. Barrett, J.A.; Cai, H.; Miao, J.; Khare, P.D.; Gonzalez, P.; Dalsing-Hernandez, J.; Sharma, G.; Chan, T.; Cooper, L.J.N.; Lebel, F. Regulated intratumoral expression of IL-12 using a RheoSwitch Therapeutic System ${ }^{\circledR}\left(\right.$ RTS $\left.^{\circledR}\right)$ gene switch as gene therapy for the treatment of glioma. Cancer Gene Ther. 2018, 25, 106-116. [CrossRef] [PubMed]

86. Riccadonna, C.; Yacoub Maroun, C.; Vuillefroy de Silly, R.; Boehler, M.; Calvo Tardón, M.; Jueliger, S.; Taverna, P.; Barba, L.; Marinari, E.; Pellegatta, S.; et al. Decitabine treatment of glioma-initiating cells enhances immune recognition and killing. PLOS ONE 2016, 11, e0162105. [CrossRef]

87. Hsu, S.P.C.; Chen, Y.C.; Chiang, H.C.; Huang, Y.C.; Huang, C.C.; Wang, H.E.; Wang, Y.S.; Chi, K.H. Rapamycin and hydroxychloroquine combination alters macrophage polarization and sensitizes glioblastoma to immune checkpoint inhibitors. J. Neurooncol. 2020, 146, 417-426. [CrossRef]

88. Ciesielski, M.J.; Bu, Y.; Munich, S.A.; Teegarden, P.; Smolinski, M.P.; Clements, J.L.; Lau, J.Y.N.; Hangauer, D.G.; Fenstermaker, R.A. KX2-361: A novel orally bioavailable small molecule dual Src/tubulin inhibitor that provides long term survival in a murine model of glioblastoma. J. Neurooncol. 2018, 140, 519-527. [CrossRef]

89. Su, Y.-T.; Butler, M.; Zhang, M.; Zhang, W.; Song, H.; Hwang, L.; Tran, A.D.; Bash, R.E.; Schorzman, A.N.; Pang, Y.; et al. MerTK inhibition decreases immune suppressive glioblastoma-associated macrophages and neoangiogenesis in glioblastoma microenvironment. Neuro-Oncol. Adv. 2020, 2, 1-13. [CrossRef]

90. McFarland, B.C.; Marks, M.P.; Rowse, A.L.; Fehling, S.C.; Gerigk, M.; Qin, H.; Benveniste, E.N. Loss of SOCS3 in myeloid cells prolongs survival in a syngeneic model of glioma. Oncotarget 2016, 7, 20621-20635. [CrossRef]

91. Leten, C.; Trekker, J.; Struys, T.; Dresselaers, T.; Gijsbers, R.; Vande Velde, G.; Lambrichts, I.; Van Der Linden, A.; Verfaillie, C.M.; Himmelreich, U. Assessment of bystander killing-mediated therapy of malignant brain tumors using a multimodal imaging approach. Stem Cell Res. Ther. 2015, 6, 163. [CrossRef] [PubMed]

92. Tong, L.; Li, J.; Li, Q.; Wang, X.; Medikonda, R.; Zhao, T.; Li, T.; Ma, H.; Yi, L.; Liu, P.; et al. ACT001 reduces the expression of PD-L1 by inhibiting the phosphorylation of STAT3 in glioblastoma. Theranostics 2020, 10, 5943-5956. [CrossRef] [PubMed]

93. Wu, J.; Waxman, D.J. Metronomic cyclophosphamide eradicates large implanted GL261 gliomas by activating antitumor Cd8+ T-cell responses and immune memory. Oncoimmunology 2015, 4, e1005521. [CrossRef]

94. Wu, J.; Jordan, M.; Waxman, D.J. Metronomic cyclophosphamide activation of anti-tumor immunity: Tumor model, mouse host, and drug schedule dependence of gene responses and their upstream regulators. BMC Cancer 2016, 16, 623. [CrossRef]

95. Wu, J.; Waxman, D.J. Metronomic cyclophosphamide schedule-dependence of innate immune cell recruitment and tumor regression in an implanted glioma model. Cancer Lett. 2014, 353, 272-280. [CrossRef]

96. Pérez, J.E.; Fritzell, S.; Kopecky, J.; Visse, E.; Darabi, A.; Siesjö, P. The effect of locally delivered cisplatin is dependent on an intact immune function in an experimental glioma model. Sci. Rep. 2019, 9, 5632. [CrossRef] 
97. Wei, J.; Nduom, E.K.; Kong, L.Y.; Hashimoto, Y.; Xu, S.; Gabrusiewicz, K.; Ling, X.; Huang, N.; Qiao, W.; Zhou, S.; et al. MiR-138 exerts anti-glioma efficacy by targeting immune checkpoints. Neuro. Oncol. 2016, 18, 639-648. [CrossRef]

98. Strong, A.D.; Indart, M.C.; Hill, N.R.; Daniels, R.L. GL261 glioma tumor cells respond to ATP with an intracellular calcium rise and glutamate release. Physiol. Behav. 2017, 176, 139-148. [CrossRef] [PubMed]

99. Han, C.J.; Zheng, J.Y.; Sun, L.; Yang, H.C.; Cao, Z.Q.; Zhang, X.H.; Zheng, L.T.; Zhen, X.C. The oncometabolite 2-hydroxyglutarate inhibits microglial activation via the AMPK/mTOR/NF-kB pathway. Acta Pharmacol. Sin. 2019, 40, 1292-1302. [CrossRef] [PubMed]

100. Panek, W.K.; Pituch, K.C.; Miska, J.; Kim, J.W.; Rashidi, A.; Kanojia, D.; Lopez-Rosas, A.; Han, Y.; Yu, D.; Chang, C.L.; et al. Local Application of Autologous Platelet Rich Fibrin Patch (PRF- P) Suppresses Regulatory T cell Recruitment in a Murine Glioma Model. Mol. Neurobiol. 2019, 176, 139-148. [CrossRef] [PubMed]

101. Bongiorno, E.K.; Garcia, S.A.; Sauma, S.; Hooper, D.C. Type 1 immune mechanisms driven by the response to infection with attenuated rabies virus result in changes in the immune bias of the tumor microenvironment and necrosis of mouse GL261 brain tumors. J. Immunol. 2017, 176, 139-148. [CrossRef]

102. Roberts, N.B.; Alqazzaz, A.; Hwang, J.R.; Qi, X.; Keegan, A.D.; Kim, A.J.; Winkles, J.A.; Woodworth, G.F. Oxaliplatin disrupts pathological features of glioma cells and associated macrophages independent of apoptosis induction. J. Neurooncol. 2018, 140, 497-507. [CrossRef] [PubMed]

103. Xu, S.; Wei, J.; Wang, F.; Kong, L.Y.; Ling, X.Y.; Nduom, E.; Gabrusiewicz, K.; Doucette, T.; Yang, Y.; Yaghi, N.K.; et al. Effect of miR-142-3p on the M2 macrophage and therapeutic efficacy against murine glioblastoma. J. Natl. Cancer Inst. 2014, $106,1-11$. [CrossRef] [PubMed]

104. Yang, J.; Liu, R.; Deng, Y.; Qian, J.; Lu, Z.; Wang, Y.; Zhang, D.; Luo, F.; Chu, Y. MiR-15a/16 deficiency enhances anti-tumor immunity of glioma-infiltrating CD8+ T cells through targeting mTOR. Int. J. Cancer 2017, 141, 2082-2092. [CrossRef] [PubMed]

105. Mukherjee, S.; Baidoo, J.N.E.; Sampat, S.; Mancuso, A.; David, L.; Cohen, L.S.; Zhou, S.; Banerjee, P. Liposomal tricurin, a synergistic combination of curcumin, epicatechin gallate and resveratrol, repolarizes tumor-associated microglia/macrophages, and eliminates glioblastoma (GBM) and GBM Stem Cells. Molecules 2018, 23, 201. [CrossRef] [PubMed]

106. Mukherjee, S.; Fried, A.; Hussaini, R.; White, R.; Baidoo, J.; Yalamanchi, S.; Banerjee, P. Phytosomal curcumin causes natural killer cell-dependent repolarization of glioblastoma (GBM) tumor-associated microglia/macrophages and elimination of GBM and GBM stem cells. J. Exp. Clin. Cancer Res. 2018, 37, 168. [CrossRef] [PubMed]

107. Lepore, F.; D'Alessandro, G.; Antonangeli, F.; Santoro, A.; Esposito, V.; Limatola, C.; Trettel, F. CXCL16/CXCR6 axis drives microglia/macrophages phenotype in physiological conditions and plays a crucial role in glioma. Front. Immunol. 2018, 9, 2750. [CrossRef]

108. Yan, J.; Kong, L.Y.; Hu, J.; Gabrusiewicz, K.; Dibra, D.; Xia, X.; Heimberger, A.B.; Li, S. FGL2 as a Multimodality Regulator of Tumor-Mediated Immune Suppression and Therapeutic Target in Gliomas. J. Natl. Cancer Inst. 2015, 107, djv137. [CrossRef]

109. Turubanova, V.D.; Balalaeva, I.V.; Mishchenko, T.A.; Catanzaro, E.; Alzeibak, R.; Peskova, N.N.; Efimova, I.; Bachert, C.; Mitroshina, E.V.; Krysko, O.; et al. Immunogenic cell death induced by a new photodynamic therapy based on photosens and photodithazine. J. Immunother. Cancer 2019, 7, 350. [CrossRef]

110. Sun, S.; Du, G.; Xue, J.; Ma, J.; Ge, M.; Wang, H.; Tian, J. PCC0208009 enhances the anti-tumor effects of temozolomide through direct inhibition and transcriptional regulation of indoleamine 2,3-dioxygenase in glioma models. Int. J. Immunopathol. Pharmacol. 2018, 32, 2058738418787991. [CrossRef]

111. Ferrer-Font, L.; Villamañan, L.; Arias-Ramos, N.; Vilardell, J.; Plana, M.; Ruzzene, M.; Pinna, L.A.; Itarte, E.; Arús, C.; Candiota, A.P. Targeting protein kinase CK2: Evaluating CX-4945 potential for GL261 glioblastoma therapy in immunocompetent mice. Pharmaceuticals 2017, 10, 24. [CrossRef] [PubMed]

112. Proske, J.; Walter, L.; Bumes, E.; Hutterer, M.; Vollmann-Zwerenz, A.; Eyüpoglu, I.Y.; Savaskan, N.E.; Seliger, C.; Hau, P.; Uhl, M. Adaptive immune response to and survival effect of temozolomide-and valproic acid-induced autophagy in glioblastoma. Anticancer Res. 2016, 36, 899-906. [PubMed]

113. Ott, M.; Kassab, C.; Marisetty, A.; Hashimoto, Y.; Wei, J.; Zamler, D.; Leu, J.S.; Tomaszowski, K.H.; Sabbagh, A.; Fang, D.; et al. Radiation with STAT3 blockade triggers dendritic cell-T cell interactions in the glioma microenvironment and therapeutic efficacy. Clin. Cancer Res. 2020, 26, 4983-4994. [CrossRef] [PubMed]

114. Li, M.; Bolduc, A.R.; Hoda, M.N.; Gamble, D.N.; Dolisca, S.B.; Bolduc, A.K.; Hoang, K.; Ashley, C.; McCall, D.; Rojiani, A.M.; et al. The indoleamine 2,3-dioxygenase pathway controls complement-dependent enhancement of chemo-radiation therapy against murine glioblastoma. J. Immunother. Cancer 2014, 2, 21. [CrossRef] [PubMed]

115. Giles, A.J.; Hutchinson, M.N.D.; Sonnemann, H.M.; Jung, J.; Fecci, P.E.; Ratnam, N.M.; Zhang, W.; Song, H.; Bailey, R.; Davis, D.; et al. Dexamethasone-induced immunosuppression: Mechanisms and implications for immunotherapy. J. Immunother. Cancer 2018, 6, 51. [CrossRef] [PubMed]

116. Ausman, J.I.; Shapiro, W.R.; Rall, D.P. Studies on the Chemotherapy of Experimental Brain Tumors: Development of an Experimental Model. Cancer Res. 1970, 30, 2394-2400. [PubMed]

117. Crommentuijn, M.H.W.; Schetters, S.T.T.; Dusoswa, S.A.; Kruijssen, L.J.W.; Garcia-Vallejo, J.J.; van Kooyk, Y. Immune involvement of the contralateral hemisphere in a glioblastoma mouse model. J. Immunother. Cancer 2020, 8, e000323. [CrossRef]

118. Baker, G.J.; Castro, M.G.; Lowenstein, P.R. Isolation and flow cytometric analysis of glioma-infiltrating peripheral blood mononuclear cells. J. Vis. Exp. 2015, 2015, e53676. [CrossRef] 
119. Baker, G.J.; Chockley, P.; Zamler, D.; Castro, M.G.; Lowenstein, P.R. Natural killer cells require monocytic Gr-1+/CD11b+ myeloid cells to eradicate orthotopically engrafted glioma cells. Oncoimmunology 2016, 5, e1163461. [CrossRef]

120. Chang, C.Y.; Jeon, S.B.; Yoon, H.J.; Choi, B.K.; Kim, S.S.; Oshima, M.; Park, E.J. Glial TLR2-driven innate immune responses and CD8 + T cell activation against brain tumor. Glia 2019, 67, 1179-1195. [CrossRef]

121. Irvin, D.K.; Jouanneau, E.; Duvall, G.; Zhang, X.X.; Zhai, Y.; Sarayba, D.; Seksenyan, A.; Panwar, A.; Black, K.L.; Wheeler, C.J. T cells enhance stem-like properties and conditional malignancy in gliomas. PLoS ONE 2010, 5, e10974. [CrossRef] [PubMed]

122. Candolfi, M.; Yagiz, K.; Wibowo, M.; Ahlzadeh, G.E.; Puntel, M.; Ghiasi, H.; Kamran, N.; Paran, C.; Lowenstein, P.R.; Castro, M.G. Temozolomide does not impair gene therapy-mediated antitumor immunity in syngeneic brain tumor models. Clin. Cancer Res. 2014, 20, 1555-1565. [CrossRef] [PubMed]

123. Luo, L.; Guan, X.; Begum, G.; Ding, D.; Gayden, J.; Hasan, M.N.; Fiesler, V.M.; Dodelson, J.; Kohanbash, G.; Hu, B.; et al. Blockade of Cell Volume Regulatory Protein NKCC1 Increases TMZ-Induced Glioma Apoptosis and Reduces Astrogliosis. Mol. Cancer Ther. 2020, 19, 1550-1561. [CrossRef] [PubMed]

124. Safdie, F.; Brandhorst, S.; Wei, M.; Wang, W.; Lee, C.; Hwang, S.; Conti, P.S.; Chen, T.C.; Longo, V.D. Fasting Enhances the Response of Glioma to Chemo- and Radiotherapy. PLoS ONE 2012, 7, e44603. [CrossRef] [PubMed]

125. Kim, T.G.; Kim, C.H.; Park, J.S.; Park, S.D.; Kim, C.K.; Chung, D.S.; Hong, Y.K. Immunological factors relating to the antitumor effect of temozolomide chemoimmunotherapy in a murine glioma model. Clin. Vaccine Immunol. 2010, 17, 143-153. [CrossRef]

126. Guan, X.; Hasan, M.N.; Begum, G.; Kohanbash, G.; Carney, K.E.; Pigott, V.M.; Persson, A.I.; Castro, M.G.; Jia, W.; Sun, D. Blockade of $\mathrm{Na} / \mathrm{H}$ exchanger stimulates glioma tumor immunogenicity and enhances combinatorial TMZ and anti-PD-1 therapy. Cell Death Dis. 2018, 9, 1010. [CrossRef]

127. Yadav, V.N.; Zamler, D.; Baker, G.J.; Kadiyala, P.; Erdreich-Epstein, A.; DeCarvalho, A.C.; Mikkelsen, T.; Castro, M.G.; Lowenstein, P.R. CXCR4 increases in-vivo glioma perivascular invasion, and reduces radiation induced apoptosis: A genetic knockdown study. Oncotarget 2016, 7, 83701-83719. [CrossRef]

128. Guan, X.; Luo, L.; Begum, G.; Kohanbash, G.; Song, Q.; Rao, A.; Amankulor, N.; Sun, B.; Sun, D.; Jia, W. Elevated Na/H exchanger 1 (SLC9A1) emerges as a marker for tumorigenesis and prognosis in gliomas. J. Exp. Clin. Cancer Res. 2018, 37, 255. [CrossRef]

129. Mineharu, Y.; Kamran, N.; Lowenstein, P.R.; Castro, M.G. Blockade of mTOR Signaling via Rapamycin Combined with Immunotherapy Augments Anti-glioma Cytotoxic and Memory T cells' Functions. Mol. Cancer Ther. 2014, 13, 3024-3036. [CrossRef]

130. Park, J.H.; Ryu, C.H.; Kim, M.J.; Jeun, S.S. Combination therapy for gliomas using temozolomide and interferon-beta secreting human bone marrow derived mesenchymal stem cells. J. Korean Neurosurg. Soc. 2015, 57, 323-328. [CrossRef]

131. Seyfried, T.N.; El-Abbadi, M.; Roy, M.L. Ganglioside distribution in murine neural tumors. Mol. Chem. Neuropathol. 1992, 17, 147-167. [CrossRef]

132. Martínez-Murillo, R.; Martínez, A. Standardization of an orthotopic mouse brain tumor model following transplantation of CT-2A astrocytoma cells. Histol. Histopathol. 2007, 22, 1309-1326. [PubMed]

133. Riva, M.; Wouters, R.; Weerasekera, A.; Belderbos, S.; Nittner, D.; Thal, D.R.; Baert, T.; Giovannoni, R.; Gsell, W.; Himmelreich, U.; et al. CT-2A neurospheres-derived high-grade glioma in mice: A new model to address tumor stem cells and immunosuppression. Biol. Open 2019, 8, bio044552. [CrossRef] [PubMed]

134. Woroniecka, K.; Chongsathidkiet, P.; Rhodin, K.; Kemeny, H.; Dechant, C.; Farber, S.H.; Elsamadicy, A.A.; Cui, X.; Koyama, S.; Jackson, C.; et al. T-cell exhaustion signatures vary with tumor type and are severe in glioblastoma. Clin. Cancer Res. 2018, 24, 4175-4186. [CrossRef] [PubMed]

135. Zhang, P.; Miska, J.; Lee-Chang, C.; Rashidi, A.; Panek, W.K.; An, S.; Zannikou, M.; Lopez-Rosas, A.; Han, Y.; Xiao, T.; et al. Therapeutic targeting of tumor-associated myeloid cells synergizes with radiation therapy for glioblastoma. Proc. Natl. Acad. Sci. USA 2019, 116, 23714-23723. [CrossRef] [PubMed]

136. Mohme, M.; Maire, C.L.; Geumann, U.; Schliffke, S.; Dührsen, L.; Fita, K.; Akyüz, N.; Binder, M.; Westphal, M.; Guenther, C.; et al. Local Intracerebral Immunomodulation Using Interleukin-Expressing Mesenchymal Stem Cells in Glioblastoma. Clin. Cancer Res. 2020, 26, 2626-2639. [CrossRef]

137. von Roemeling, C.A.; Wang, Y.; Qie, Y.; Yuan, H.; Zhao, H.; Liu, X.; Yang, Z.; Yang, M.; Deng, W.; Bruno, K.A.; et al. Therapeutic modulation of phagocytosis in glioblastoma can activate both innate and adaptive antitumour immunity. Nat. Commun. 2020, 11, 1508. [CrossRef]

138. Lamano, J.B.; Lamano, J.B.; Li, Y.D.; DiDomenico, J.D.; Choy, W.; Veliceasa, D.; Oyon, D.E.; Fakurnejad, S.; Ampie, L.; Kesavabhotla, K.; et al. Glioblastoma-derived IL6 induces immunosuppressive peripheral myeloid cell PD-L1 and promotes tumor growth. Clin. Cancer Res. 2019, 25, 3643-3657. [CrossRef]

139. Woroniecka, K.I.; Rhodin, K.E.; Dechant, C.; Cui, X.; Chongsathidkiet, P.; Wilkinson, D.; Waibl-Polania, J.; Sanchez-Perez, L.; Fecci, P.E. 4-1BB agonism averts Til exhaustion and licenses PD-1 blockade in glioblastoma and other intracranial cancers. Clin. Cancer Res. 2020, 26, 1349-1358. [CrossRef]

140. Speranza, M.C.; Passaro, C.; Ricklefs, F.; Kasai, K.; Klein, S.R.; Nakashima, H.; Kaufmann, J.K.; Ahmed, A.K.; Nowicki, M.O.; Obi, P.; et al. Preclinical investigation of combined gene-mediated cytotoxic immunotherapy and immune checkpoint blockade in glioblastoma. Neuro. Oncol. 2018, 20, 225-235. [CrossRef]

141. Passaro, C.; Alayo, Q.; DeLaura, I.; McNulty, J.; Grauwet, K.; Ito, H.; Bhaskaran, V.; Mineo, M.; Lawler, S.E.; Shah, K.; et al. Erratum: Arming an oncolytic herpes simplex virus type 1 with a single-chain fragment variable antibody against PD-1 for experimental glioblastoma therapy. Clin. Cancer Res. 2020, 26, 758. [CrossRef] [PubMed] 
142. Belcaid, Z.; Berrevoets, C.; Choi, J.; van Beelen, E.; Stavrakaki, E.; Pierson, T.; Kloezeman, J.; Routkevitch, D.; van der Kaaij, M.; van der Ploeg, A.; et al. Low-dose oncolytic adenovirus therapy overcomes tumor-induced immune suppression and sensitizes intracranial gliomas to anti-PD-1 therapy. Neuro-Oncology Adv. 2020, 2, vdaa011. [CrossRef] [PubMed]

143. Liu, C.J.; Schaettler, M.; Blaha, D.T.; Bowman-Kirigin, J.A.; Kobayashi, D.K.; Livingstone, A.J.; Bender, D.; Miller, C.A.; Kranz, D.M.; Johanns, T.M.; et al. Treatment of an aggressive orthotopic murine glioblastoma model with combination checkpoint blockade and a multivalent neoantigen vaccine. Neuro. Oncol. 2020, 22, 1276-1288. [CrossRef] [PubMed]

144. Balathasan, L.; Tang, V.A.; Yadollahi, B.; Brun, J.; Labelle, M.; Lefebvre, C.; Swift, S.L.; Stojdl, D.F. Activating Peripheral Innate Immunity Enables Safe and Effective Oncolytic Virotherapy in the Brain. Mol. Ther. Oncolytics 2017, 7, 45-56. [CrossRef]

145. Sarén, T.; Ramachandran, M.; Martikainen, M.; Yu, D. Insertion of the Type-I IFN Decoy Receptor B18R in a miRNA-Tagged Semliki Forest Virus Improves Oncolytic Capacity but Results in Neurotoxicity. Mol. Ther. Oncolytics 2017, 7, 67-75. [CrossRef]

146. Ramachandran, M.; Yu, D.; Dyczynski, M.; Baskaran, S.; Zhang, L.; Lulla, A.; Lulla, V.; Saul, S.; Nelander, S.; Dimberg, A.; et al. Safe and effective treatment of experimental neuroblastoma and glioblastoma using systemically delivered triple microrna-detargeted oncolytic semliki forest virus. Clin. Cancer Res. 2017, 23, 1519-1530. [CrossRef]

147. Dutta, S.; Sengupta, P. Men and mice: Relating their ages. Life Sci. 2016, 152, 244-248. [CrossRef]

148. Fraser, H. Astrocytomas in an inbred mouse strain. J. Pathol. 1971, 103, 266-270. [CrossRef]

149. Serano, R.D.; Pegram, C.N.; Bigner, D.D. Tumorigenic cell culture lines from a spontaneous VM/Dk murine astrocytoma (SMA). Acta Neuropathol. 1980, 51, 53-64. [CrossRef]

150. Learn, C.A.; Grossi, P.M.; Schmittling, R.J.; Xie, W.; Mitchell, D.A.; Karikari, I.; Wei, Z.; Dressman, H.; Sampson, J.H. Genetic analysis of intracranial tumors in a murine model of glioma demonstrate a shift in gene expression in response to host immunity. J. Neuroimmunol. 2007, 182, 63-72. [CrossRef]

151. Tran, T.T.; Uhl, M.; Ma, J.Y.; Janssen, L.; Sriram, V.; Aulwurm, S.; Kerr, I.; Lam, A.; Webb, H.K.; Kapoun, A.M.; et al. Inhibiting TGF- $\beta$ signaling restores immune surveillance in the SMA-560 glioma model. Neuro. Oncol. 2007, 9, 259-270. [CrossRef] [PubMed]

152. Ahmad, M.; Frei, K.; Willscher, E.; Stefanski, A.; Kaulich, K.; Roth, P.; Stühler, K.; Reifenberger, G.; Binder, H.; Weller, M. How stemlike are sphere cultures from long-term cancer cell lines? Lessons from mouse glioma models. J. Neuropathol. Exp. Neurol. 2014, 73, 1062-1077. [CrossRef] [PubMed]

153. Schneider, H.; Lohmann, B.; Wirsching, H.G.; Hasenbach, K.; Rushing, E.J.; Frei, K.; Pruschy, M.; Tabatabai, G.; Weller, M. Age-associated and therapy-induced alterations in the cellular microenvironment of experimental gliomas. Oncotarget 2017, 8, 87124-87135. [CrossRef] [PubMed]

154. Schötterl, S.; Huber, S.M.; Lentzen, H.; Mittelbronn, M.; Naumann, U. Adjuvant Therapy Using Mistletoe Containing Drugs Boosts the T-Cell-Mediated Killing of Glioma Cells and Prolongs the Survival of Glioma Bearing Mice. Evidence-Based Complement. Altern. Med. 2018, 2018, 3928572. [CrossRef] [PubMed]

155. Schneider, H.; Szabo, E.; Machado, R.A.; Broggini-Tenzer, A.; Walter, A.; Lobell, M.; Heldmann, D.; Süssmeier, F.; Grünewald, S.; Weller, M. Novel TIE-2 inhibitor BAY-826 displays in vivo efficacy in experimental syngeneic murine glioma models. J. Neurochem. 2017, 140, 170-182. [CrossRef]

156. Seystahl, K.; Papachristodoulou, A.; Burghardt, I.; Schneider, H.; Hasenbach, K.; Janicot, M.; Roth, P.; Weller, M. Biological role and therapeutic targeting of TGF- $\beta_{3}$ in glioblastoma. Mol. Cancer Ther. 2017, 16, 1177-1186. [CrossRef]

157. Silginer, M.; Weller, M.; Ziegler, U.; Roth, P. Integrin inhibition promotes atypical anoikis in glioma cells. Cell Death Dis. 2014, 5 , e1012-e1013. [CrossRef]

158. Papachristodoulou, A.; Silginer, M.; Weller, M.; Schneider, H.; Hasenbach, K.; Janicot, M.; Roth, P. Therapeutic targeting of TGFb ligands in glioblastoma using novel antisense oligonucleotides reduces the growth of experimental gliomas. Clin. Cancer Res. 2019, 25, 7189-7201. [CrossRef]

159. Pituch, K.C.; Miska, J.; Krenciute, G.; Panek, W.K.; Li, G.; Rodriguez-Cruz, T.; Wu, M.; Han, Y.; Lesniak, M.S.; Gottschalk, S.; et al. Adoptive Transfer of IL13R $\alpha 2$-Specific Chimeric Antigen Receptor T Cells Creates a Pro-inflammatory Environment in Glioblastoma. Mol. Ther. 2018, 26, 986-995. [CrossRef]

160. Kovacs, Z.; Werner, B.; Rassi, A.; Sass, J.O.; Martin-Fiori, E.; Bernasconi, M. Prolonged survival upon ultrasound-enhanced doxorubicin delivery in two syngenic glioblastoma mouse models. J. Control. Release 2014, 187, 74-82. [CrossRef]

161. Weiner, N.; Pyles, R.B.; Chalk, C.L.; Balko, M.G.; Miller, M.A.; Dyer, C.A.; Warnick, R.E.; Parysek, L.M. A syngeneic mouse glioma model for study of glioblastoma therapy. J. Neuropathol. Exp. Neurol. 1999, 58, 54-60. [CrossRef] [PubMed]

162. Gazdzinski, L.M.; Nieman, B.J. Cellularimaging and texture analysis distinguish differences in cellular dynamics in mouse brain tumors. Magn. Reson. Med. 2014, 71, 1531-1541. [CrossRef] [PubMed]

163. Lobo, M.R.; Wang, X.; Gillespie, G.Y.; Woltjer, R.L.; Pike, M.M. Combined efficacy of cediranib and quinacrine in glioma is enhanced by hypoxia and causally linked to autophagic vacuole accumulation. PLoS ONE 2014, 9, e114110. [CrossRef] [PubMed]

164. Lobo, M.R.; Kukino, A.; Tran, H.; Schabel, M.C.; Springer, C.S., Jr.; Gillespie, G.Y.; Grafe, M.R.; Woltjer, R.L.; Pike, M.M. Synergistic antivascular and antitumor efficacy with combined cediranib and SC6889 in intracranial mouse glioma. PLoS ONE 2015, 10, e0144488. [CrossRef]

165. Hellums, E.K.; Markert, J.M.; Parker, J.N.; He, B.; Perbal, B.; Roizman, B.; Whitley, R.J.; Langford, C.P.; Bharara, S.; Gillespie, G.Y. Increased efficacy of an interleukin-12-secreting herpes simplex virus in a syngeneic intracranial murine glioma model. Neuro. Oncol. 2005, 7, 213-224. [CrossRef] 
166. Flores, C.; Pham, C.; Snyder, D.; Yang, S.; Sanchez-Perez, L.; Sayour, E.; Cui, X.; Kemeny, H.; Friedman, H.; Bigner, D.D.; et al. Novel role of hematopoietic stem cells in immunologic rejection of malignant gliomas. Oncoimmunology 2015, 4, e994374. [CrossRef] [PubMed]

167. Pérez, J.E.; Kopecky, J.; Visse, E.; Darabi, A.; Siesjö, P. Convection-enhanced delivery of temozolomide and whole cell tumor immunizations in GL261 and KR158 experimental mouse gliomas. BMC Cancer 2020, $20,7$.

168. Flores-Toro, J.A.; Luo, D.; Gopinath, A.; Sarkisian, M.R.; Campbell, J.J.; Charo, I.F.; Singh, R.; Schall, T.J.; Datta, M.; Jain, R.K.; et al. CCR2 inhibition reduces tumor myeloid cells and unmasks a checkpoint inhibitor effect to slow progression of resistant murine gliomas. Proc. Natl. Acad. Sci. USA 2020, 117, 1129-1138. [CrossRef]

169. Kwon, C.H.; Zhao, D.; Chen, J.; Alcantara, S.; Li, Y.; Burns, D.K.; Mason, R.P.; Lee, E.Y.; Wu, H.; Parada, L.F. Pten haploinsufficiency accelerates formation of high-grade astrocytomas. Cancer Res. 2008, 68, 3286-3294. [CrossRef]

170. Llaguno, S.A.; Chen, J.; Kwon, C.H.; Jackson, E.L.; Li, Y.; Burns, D.K.; Alvarez-Buylla, A.; Parada, L.F. Malignant Astrocytomas Originate from Neural Stem/Progenitor Cells in a Somatic Tumor Suppressor Mouse Model. Cancer Cell 2009, 15, 45-56. [CrossRef]

171. Soda, Y.; Marumoto, T.; Friedmann-Morvinski, D.; Soda, M.; Liu, F.; Michiue, H.; Pastorino, S.; Yang, M.; Hoffman, R.M.; Kesari, S.; et al. Transdifferentiation of glioblastoma cells into vascular endothelial cells. Proc. Natl. Acad. Sci. USA 2011, 108, 4274-4280. [CrossRef] [PubMed]

172. Saha, D.; Martuza, R.L.; Rabkin, S.D. Macrophage Polarization Contributes to Glioblastoma Eradication by Combination Immunovirotherapy and Immune Checkpoint Blockade. Cancer Cell 2017, 32, 253-267. [CrossRef] [PubMed]

173. Cheema, T.A.; Wakimoto, H.; Fecci, P.E.; Ning, J.; Kuroda, T.; Jeyaretna, D.S.; Martuza, R.L.; Rabkin, S.D. Multifaceted oncolytic virus therapy for glioblastoma in an immunocompetent cancer stem cell model. Proc. Natl. Acad. Sci. USA 2013, 110, 12006-12011. [CrossRef] [PubMed]

174. Saha, D.; Rabkin, S.D.; Martuza, R.L. Temozolomide antagonizes oncolytic immunovirotherapy in glioblastoma. J. Immunother. Cancer 2020, 8, 345. [CrossRef]

175. Saha, D.; Wakimoto, H.; Peters, C.W.; Antoszczyk, S.J.; Rabkin, S.D.; Martuza, R.L. Combinatorial effects of vegfr kinase inhibitor axitinib and oncolytic virotherapy in mouse and human glioblastoma stem-like cell models. Clin. Cancer Res. 2018, 24, 3409-3422. [CrossRef]

176. Osuka, S.; Sampetrean, O.; Shimizu, T.; Saga, I.; Onishi, N.; Sugihara, E.; Okubo, J.; Fujita, S.; Takano, S.; Matsumura, A.; et al. IGF1 receptor signaling regulates adaptive radioprotection in glioma stem cells. Stem Cells 2013, 31, 627-640. [CrossRef]

177. He, B.; Jabouille, A.; Steri, V.; Johansson-Percival, A.; Michael, I.P.; Kotamraju, V.R.; Junckerstorff, R.; Nowak, A.K.; Hamzah, J.; Lee, G.; et al. Vascular targeting of LIGHT normalizes blood vessels in primary brain cancer and induces intratumoural high endothelial venules. J. Pathol. 2018, 245, 209-221. [CrossRef]

178. Riva, M.; Wouters, R.; Nittner, D.; Ceuster, J.; Sterpin, E.; Giovannoni, R.; Himmelreich, U.; Gsell, W.; Van Ranst, M.; Coosemans, A. Radiation dose-escalation and dose-fractionation modulate the immune microenvironment, cancer stem cells and vasculature in experimental high-grade gliomas. J. Neurosurg. Sci. 2020. [CrossRef]

179. Costa, B.; Fletcher, M.; Boskovic, P.; Ivanova, E.L.; Eisemann, T.; Lohr, S.; Bunse, L.; Löwer, M.; Burchard, S.; Korshunov, A.; et al. A novel neural stem cell-derived immunocompetent mouse model of glioblastoma for preclinical studies. bioRxiv 2020. [CrossRef]

180. Aslan, K.; Turco, V.; Blobner, J.; Sonner, J.K.; Liuzzi, A.R.; Núñez, N.G.; De Feo, D.; Kickingereder, P.; Fischer, M.; Green, E.; et al. Heterogeneity of response to immune checkpoint blockade in hypermutated experimental gliomas. Nature Comm 2020, $11,931$. [CrossRef]

181. Schafer, N.; Gielen, G.H.; Rauschenbach, L.; Kebir, S.; Till, A.; Reinartz, R.; Simon, M.; Niehusmann, P.; Kleinschnitz, C.; Herrlinger, U.; et al. Longitudinal heterogeneity in glioblastoma: Moving targets in recurrent versus primary tumors. J. Transl. Med. 2019, 17, 96. [CrossRef] [PubMed] 